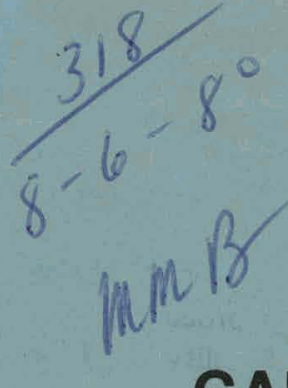

\title{
GALVANOSTATIC POLARIZATION OF ZINC MICROANODES IN KOH ELECTROLYTES
}

\author{
by \\ Ming-Biann Liu, G. M. Cook, \\ and N. P. Yao
}

ARGONNE NATIONAL LABORATORY, ARGONNE, ILLINOIS

Prepared for the U. S. DEPARTMENT OF ENERGY

under Contract W-31-109-Eng-38 


\section{DISCLAIMER}

This report was prepared as an account of work sponsored by an agency of the United States Government. Neither the United States Government nor any agency Thereof, nor any of their employees, makes any warranty, express or implied, or assumes any legal liability or responsibility for the accuracy, completeness, or usefulness of any information, apparatus, product, or process disclosed, or represents that its use would not infringe privately owned rights. Reference herein to any specific commercial product, process, or service by trade name, trademark, manufacturer, or otherwise does not necessarily constitute or imply its endorsement, recommendation, or favoring by the United States Government or any agency thereof. The views and opinions of authors expressed herein do not necessarily state or reflect those of the United States Government or any agency thereof. 


\section{DISCLAIMER}

Portions of this document may be illegible in electronic image products. Images are produced from the best available original document. 
The facilities of Argonne National Laboratory are owned by the United States Government. Under the terms of a contract (W-31-109-Eng-38) among the U. S. Department of Energy, Argonne Universities Association and The University of Chicago, the University employs the staff and operates the Laboratory in accordance with policies and programs formulated, approved and reviewed by the Association.

\section{MEMBERS OF ARGONNE UNIVERSITIES ASSOCIATION}

The University of Arizona

Carnegie-Mellon University

Case Western Reserve University

The University of Chicago

University of Cincinnati

Illinois Institute of Technology

University of Illinois

Indiana University

The University of Iowa

Iowa State University
The University of Kansas

Kansas State University

Loyola University of Chicago

Marquette University

The University of Michigan

Michigan State University

University of Minnesota

University of Missouri

Northwestern University

University of Notre Dame
The Ohio State University

Ohio University

The Pennsylvania State University

Purdue University

Saint Louis University

Southern Illinois University

The University of Texas at Austin

Washington University

Wayne State University

The University of Wisconsin-Madison

NOTICE

This report was prepared as an account of work sponsored by an agency of the United States Government. Neither the United States Government or any agency thereof, nor any of their employees, make any warranty, express or implied, or assume any legal liability or responsibility for the accuracy, completeness, or usefulness of any information, apparatus, product, or process disclosed, or represent that its use would not infringe privately owned rights. Reference herein to any specific commercial product, process, or service by trade name, mark, manufacturer, or otherwise, does not necessarily constitute or imply its endorsement, recommendation, or favoring by the United States Government or any agency thereof. The views and opinions of authors expressed herein do not necessarily state or reflect those of the United States Government or any agency thereof.

Printed in the United States of America

Available from

National Technical Information Service

U. S. Department of Commerce

5285 Port Royal Road

Springfield, VA 22161

NTIS price codes

Printed copy: A03

Microfiche copy: A01 
Distribution Category:

Energy Storage--ElectrochemicalNearterm Batteries (UC-94ca)

ANL/OEPM-80-1

ARGONNE NATIONAL LABORATORY

9700 South Cass Avenue

Argonne, Illinois 60439

GALVANOSTATIC POLARIZATION OF ZINC

MICROANODES IN KOH ELECTROLYTES

$\Longleftarrow$

by

Ming-Biann Liu, G. M. Cook; and N. P. Yao

Chemical Engineering Division

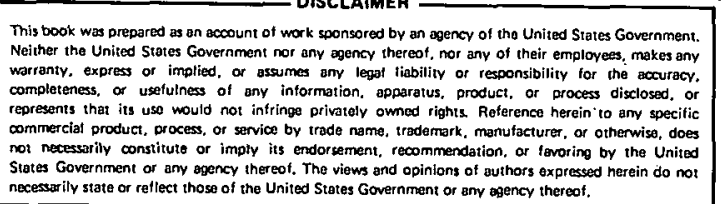

May 1980 . 
THIS PAGE

\section{WAS INTENTIONALLY LEFT BLANK}




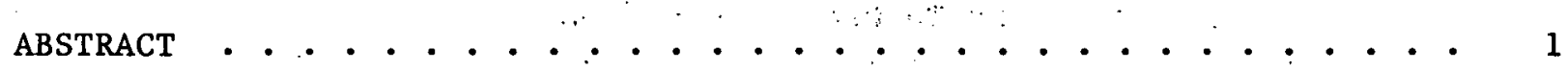

I. INTRODUCTION $\because$. . . . . . . . . . . . . . . . . 2

II. EXPERIMENTAL . . . . . . . . . . . . . . . . . . 4

III. RESULTS . . . . . . . . . . . . . . . . . . . 5

IV . DISCUSSION AND CONCLUSIONS . . . . . . . . . . . . . . 9

A. One-Dimensional Diffusion Model ............. 9

B. Comparison with Previous Studies ............. 11

V. PROPOSED ANODIC PROCESSES OF ZINC . . . . . . . . . . . . . . . 14

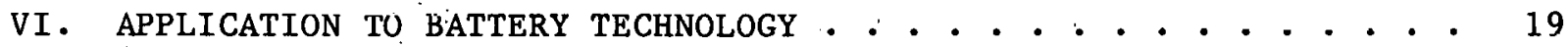

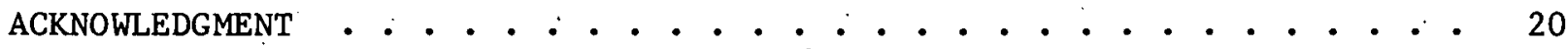

APPENDIX . . . . . . . . . . . . . . . . . . . . . . . 22

REFERENCES • . . . . . . . . . . . . . . . . . . . 26 


\section{LIST OF FIGURES}

No. Title

1. Experimental Apparatus for Testing of Zinc Anodes

in $\mathrm{KOH}$ Electrolyte . . . . . . . . . . . . . . . . . . . 4

2. Current Density vs. Passivation Time of the Zinc Anode

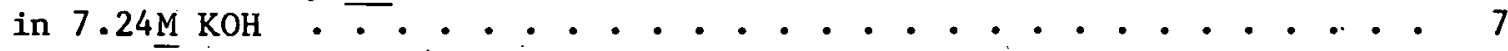

3. Current Density vs. Passivation Time for Facing-Upward Anode in $7.24 \mathrm{M}, 4.98 \mathrm{M}, 2.92 \mathrm{M}$, and $0.784 \underline{\mathrm{M}}$ KOH Electrolyte . . . . . . . . . . . . . . . . . ... : 7

4. Chronopotentiograms of Zinc Microanodes . . . . . . . . . . . 13

5. Proposed Scheme for the Processes Associated with the Anodic Passivation of Zinc in Alkaline Solutions . . . . . . . . 15

6. Current Density vs. Passivation Times for Zinc Anodes" in 2.0 and $2.8 \mathrm{M} \overline{\mathrm{KOH}}$........................ 16

7. Current Density vs. Passivation Time for Facing-Upward Zinc Anodes in $7 \overline{.2} 4 \underline{\mathrm{MOH}}$

\section{LIST OF TABLES}

No.

1. Galvanostatic Polarization of Zinc Anodes in $7.24 \mathrm{M} \mathrm{KOH}$ Electrolytes at Room Temperature ... . . . . . . . . . . 6

2. Galvanostatic Polarization of the Facing-Upward Zinc Anodes in Three Concentrations of $\mathrm{KOH}$ Electrolyte at Room Temperature . . . . . . . . . . . . . . . . . . 8

3. The Correlation Constants of the Zinc Anodes . . . . . . . . . . 9

4. Comparison of the Experimental Values of Correlation Constants 
GALVANOSTATIC POLARIZATION OF ZINC MICRO-ANODES IN KOH ELECTROLYTES

by

Ming-Biann Liu, G. M. Cook, and N. P. Yao

\section{ABSTRACT}

This report includes a critical review of the current literature on the anodic passivation of zinc electrodes, a description of supplementary experimental studies to extend. the data to a low current density region and to provide a basis for evaluating conflicting results of published work, and a new interpretation of the anodic passivation mechanism. This work provides a starting point for understanding passivation phenomena in battery electrodes.

The utilization of a zinc electrode in alkaline batteries depends on the ability of the electrode to remain active during the anodic dissolution process. This dissolution period is of ten terminated by the onset of passivation. Previous researchers have typically correlated the current density, $i$, and the passivation time, $t$, by the equation $\left(i-i_{e}\right) t^{1 / 2}=k$, where $i_{e}$ corresponds to diffusion-excluded convective current density, and $k$ is the correlation constant. Their investigations of passivation show that the values of $i_{e}$ and $k$ depend on experimental conditions such as electrode orientation.

We conducted further experiments on the effects of current density on passivation time of a small zinc anode $\left(6.6 \times 10^{-3} \mathrm{~cm}^{2}\right)$. in $\mathrm{KOH}$ at concentrations of $0.784,2.92,4.98$ and $7.24 \mathrm{M} \mathrm{KOH}$ as well as $7.24 \mathrm{M} \mathrm{KOH}$ saturated with zinc oxide. We have concluded that there are two mechanisms for anodic passivation, one occurring at current densities below about $150 \mathrm{~mA} / \mathrm{cm}^{2}$ and another at higher current densities. Accordingly, in the overall mechanism, the total time to passivation includes the times to achleve the maximum zincate concentration as well as to form porous type I $\mathrm{ZnO}$ and compact type II $\mathrm{ZnO}$.

In $\mathrm{Ni} / \mathrm{Zn}$ batteries under development for vehicle propulsion, the electrolyte is usually $30 \% \mathrm{KOH} \mathrm{(7M)} \mathrm{saturated} \mathrm{with} \mathrm{zinc} \mathrm{oxide;}$ and the zinc electrode is formed in-situ by electro-deposition of zinc onto the grid. Using the data from our tests, we were able to estimate the effect of passivation on the utilization of the zinc electrode in an alkaline battery. For our calculations, we assumed a current density of $20 \mathrm{~mA} / \mathrm{cm}^{2}$ for $a \mathrm{Ni} / \mathrm{Zn}$ battery cycled at $2-\mathrm{h}$ rate. Based on a knowledge of the structure of zinc electrodeposits, we estimated that the zinc electrode has a porosity of 0.6 at the fully charged state. Using data available in the literature and our own data, we calculated a current density of $338 \mathrm{~mA} / \mathrm{cm}^{2}$ to be that above which the passivation limits the utilization of the zinc electrode. 


\section{INTRODUCTION}

Alkaline batteries employing zinc electrodes are under development for use as near-term batteries for electric vehicles. Knowledge of the electrode behavior in $\mathrm{KOH}$ electrolyte is an important aspect of this development effort.

The utilization of a zinc electrode in alkaline batteries depends on the ability of the electrode to remain active in the anodic dissolution process:

$$
\mathrm{Zn}+4 \mathrm{OH}^{-} \longrightarrow \mathrm{Zn}(\mathrm{OH})_{4}^{2-}+2 \mathrm{e}^{\circ}
$$

At anodic potentials near the equilibrium value, the oxidation product of zinc in concentrated alkaline solutions is $\mathrm{Zn}(\mathrm{OH}){ }_{4}^{-}$as evidenced by NMR (nuclear magnetic resonance) studies $1-3$ as well as Raman and infrared reflection spectral study.2 Many workers ${ }^{4-14}$ have made galvanostatic measurements of planar zinc electrodes in alkaline solution; a general feature of the termination of the active dissolution period was found to be the onset of passivation with a sudden change toward positive potentials and oxygen evolution. Hampson et a1.15,16 observed that the transition of a porous electrode from an active to a passive condition was not so abrupt as that for a planar zinc electrode; and was accompanied by a gradual increase in electrode potential corresponding to the penetration of the reaction into the depth of the anode as pore surfaces became blocked or passivated with.oxide.

Three different mechanisms have been proposed to explain zinc passivation behavior in alkaline solutions, namely, dissolution-precipitation, adsorption, and nucleation and two-dimensional growth of crystals. In the dissolutionprecipitation model,11,13,17,18 zincate builds up in the solution layer in the vicinity of the electrode surface as dissolution proceeds until the concentration reaches a critical value corresponding to the "solubility" of zinc in the solution. At this point, the precipitation of $\mathrm{ZnO}$ or $\mathrm{Zn}(\mathrm{OH})_{2}$ occurs and subsequently retards the dissolution of zinc. This latter effect results in a rapid rise in potential until oxygen evolution begins. In the adsorption model, 19,20 hydroxide is adsorbed by the zinc electrode to form a monolayer of $\mathrm{Zn}(\mathrm{OH})_{2}$, which releases protons to form a passive zinc-oxide film, thereby retarding the diffusion of hydroxide ion. When the diffusion rate of hydroxide ions is not, sufficient to support the anodic current, passivation occurs. In the nucleation and crystal growth model,21,22 zinc oxide nuclei form on the surface, and passivation occurs when the surface is inactivated by a full coverage of $\mathrm{ZnO}$ monolayer.

In all three mechanisms, the zinc oxide film is respnnsible for passivation. Using $X$-ray analysis, Powers 23 identifled $2 n 0$ as the passive film; however; this analysis method, which requires the removal and subsequent drying 
of the passive film, could have converted all the species to $\mathrm{ZnO}$. In-situ identification data of the passivation film are not avallable. Two other hypotheses are that this film consists of either an underlying layer of $\mathrm{Zn}(\mathrm{OH})_{2}$ with an overlay of $\mathrm{ZnO}^{24-26}$ or a dual layer of $\mathrm{ZnO}$, one formed by precipitation and the other by surface growth processes.17,27 Powers and Breiter 17 considered the latter to be the cause of passivation. Recent results of optical and scanning electron microscopical observations $17,18,28,29$ have indicated that the anodic formation of $\mathrm{ZnO}$ probably occurs via the precipitation-dissolution route. Szpak and Gabriel18 illustrated that the sequential events of the dissolution-precipitation path for anodic $\mathrm{ZnO}$ formation are as follows:

(a) establishment of a quasi-equilibrium adsorption region adjacent to the electrode; (b) development of a mass transport region next to the adsorption region; (c) formation of a polymerization region in which monomers are trapped; (d) transformation of the polymerization region into a nucleation and growth. region; (e) formation of a zinc oxide film by merging of crystallites at the surface of the adsorption layer and subsequent growth of that film; and (f) collapse of oxide film due to mechanical factors resulting from the densi-. fication of the region adjacent to the adsorption region to reactivate zinc dissolution.

A number of investigators ${ }^{7-14}$ have studied the correlation between current density and passivation time in the zinc electrode. A summary of these data reported in the literature is given in an Appendix. The current density, 1 , and passivation time, $t$, have been typically correlated by the equation,

$$
\left(i-i_{e}\right) t^{1 / 2}=k
$$

where $i_{e}$ corresponds to diffusion-excluded convective current density, and $k$. is a correlation constant. Equation 2 suggests that there is a current density, $i_{e}$, below which passivation will not occur. Assuming that during anodic dissolution the formation of a "critical" concentration of zincate at the electrode causes passivation and assuming that diffusion is the only mode of mass transport, Dirkse and Hampson 13 derived the equation:

$$
i\left(t^{1 / 2}\right)=\left(C_{c r i t}-C_{b}\right) n F\left(\frac{\pi D}{4}\right)^{1 / 2}
$$

where $\mathrm{C}_{\text {crit }}$ is the "critical" concentration of zincate for the precipitation of $\mathrm{ZnO}, \mathrm{C}_{\mathrm{b}}$ is the bulk concentration of zincate, $\mathrm{n}$ is the valency change of the electrode reaction, $F$ is Faraday's constant, and $D$ is the diffusion coefficlent of zincate. Yamashita et al.14 concluded from their chronoellipsometric study that two types of Zno films form--type I film at time $t_{1}$ and type II film at $t_{2}$--during galvanostatic oxidation. The correlation of current density and $t_{1}$ can be described by $\mathrm{Eq}$. 3 , while that of current density and $t_{2}$ can be represented by Eq. 2. Elder 12 interpreted the anodic characteristics of zinc in alkaline solution as a kinetically controlled process preceding a diffusion step, so that

$$
I\left(t^{1 / 2}\right)=k_{0}-k_{1} \cdot 1
$$


In summary, a review of the literature showed that zinc oxide is responsible for passivation of the zinc anode and that the presently accepted mechanism for the formation of this zinc oxide is a precipitation-dissolution model. The correlation between passivation time and current density has been typically expressed by $\mathrm{Eq} .2$. In our investigations, we conducted further experiments on the effects of current density (from 30 up to $1620 \mathrm{~mA} / \mathrm{cm}^{2}$ ) on passivation time of a small zinc anode with a $\mathrm{KOH}$ electrolyte (0.784 to 7.24M) in an experimental cell-testing apparatus. From these data, we estimated the effect of passivation time on the utilization of a zinc anode in an alkaline battery.

\section{II . EXPERIMENTAL}

Zinc electrodes were cut into dimensions of 0.05 by $0.13 \mathrm{~cm}$ from a $z$ inc sheet of $99.99 \%$ purity purchased from United Mineral \& Chemical Corp. (New York, $\mathrm{NY}$ ). The impurities are as follows: $\mathrm{Cd}, 5 \mathrm{ppm} ; \mathrm{Pb}, 5 \mathrm{ppm} ; \mathrm{Fe}, 3$.ppm; $\mathrm{Cu}, 2 \mathrm{ppm} ; \mathrm{Au}, 1 \mathrm{ppm} ; \mathrm{Sn}, 1 \mathrm{ppm} ; \mathrm{Ge}, 0.5 \mathrm{ppm} ;$ and $\mathrm{In}, 0.5 \mathrm{ppm}$. The zinc electrodes were prepared for testing by polishing them with emery paper (No. 600). After preparation, they were horizontally mounted in an experimental apparatus (see Fig. 1) in either the facing-upward or-downward position.

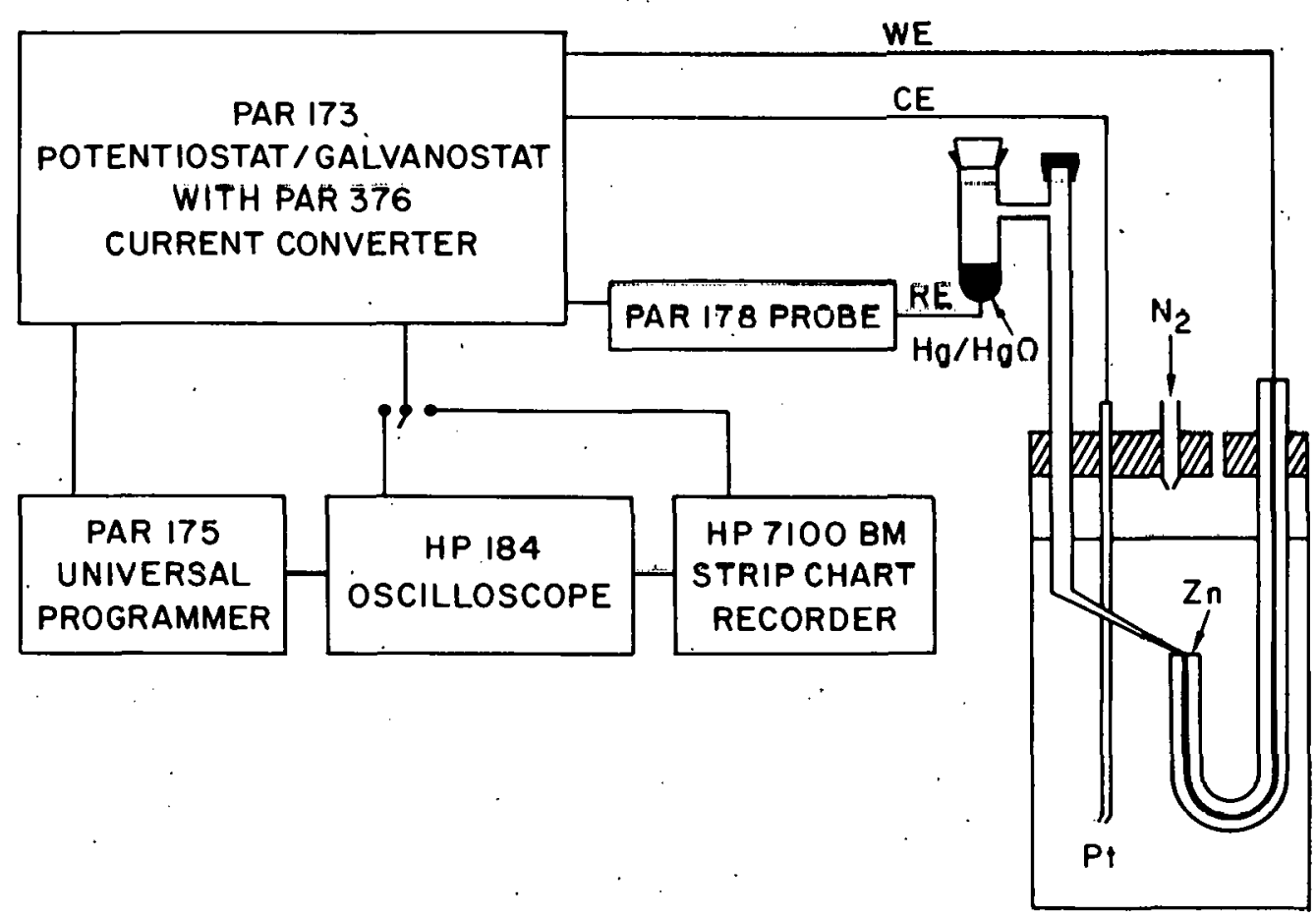

Fig. 1. Experimental Apparatus for Testing of Zinc Anodes in $\mathrm{KOH}$ Electrolyte ( $\mathrm{CE}=$ counter electrode, $\mathrm{WE}=$ working electrode, and $\mathrm{RE}=$ reference electrode) 
To eliminate edge effects, these zinc electrodes were set in acrylic plastic purchased from Fulton Products Corp. (Saxonberg, PA). The electrolyte was $\mathrm{KOH}$ at concentrations of $0.784,2.92,4.98$, and $7.24 \mathrm{M}$; in addition, $7.24 \mathrm{M} \mathrm{KOH}$ saturated with zinc oxide was also used. The KOH was reagent grade, and the zinc oxide was analytical reagent quality. The above electrolyte solutions were prepared with doubly distilled water and deaerated by passing a stream of purified nitrogen through. The counter electrode was a $1-\mathrm{cm}$ wide platinum strip. The anode potential was measured with an $\mathrm{Hg} / \mathrm{HgO}$ reference electrode in conjunction with a Luggin capillary that had been placed as close to the anode surface as practical. A Model 173 Potentiostat/Galvanostat equipped with a Model 376 Current Converter (Princeton Applied Research Corp., Princeton, NJ) was used to provide constant current. The passivation time was determined to the instant that the anode potential was seen to increase rapidly. For a passivation time less than $6 \mathrm{~s}$, a Model 184A Oscilloscope with a Model 1805A Dual Channel Vertical Amplifier and a Model 1825A Time Base and Delay Generator (Hewlett-Packard: Co., Palo Alto, CA) was used to record the potential as a function of time; for a passivation time longer than $6 \mathrm{~s}$, a Model 7100BM Strip Chart Recorder (Hewlett-Packard) was used. A Model 175 Universal Programmer (Princeton Applied Research) was programmed to trigger the potentiostat/ galvanostat and the oscilloscope simultaneously.

The passivation times of the zinc electrodes polarized at a wide range of current densities were measured at room temperature $\left(20^{\circ} \mathrm{C}\right)$. Before each measurement, the zinc electrode was anodically etched at $10 \mu \mathrm{A}$ for $5 \mathrm{~s}$. After waiting for at least $10 \mathrm{~min}$ to ensure a quiescent state of the electrolyte and the establishment of electrode equilibrium state, polarization was commenced. Once passivated, electrodes were repolished. Potential/time oscilloscope traces were recorded photographically. Measurements were sometimes repeated to ensure reproducibility.

\section{RESULTS}

Table 1 lists the passivation time of facing-upward and -downward zinc microelectrodes discharged at current densities ranging from 61 to $1620 \mathrm{~mA} / \mathrm{cm}^{2}$ in $7.24 \mathrm{M} \mathrm{KOH}$ electrolyte, as well as the passivation time of facing-upward electrodes discharged at 122 to $1530 \mathrm{~mA} / \mathrm{cm}^{2}$ in $\mathrm{KOH}$ saturated with $\mathrm{ZnO}$. At some current densities, more than one passivation measurement was made to check the reproducibility of the test results. In addition, data were obtained using an electrode with about $1-\mathrm{mm}$ deep plastic channel to reduce natural convection. The data in Table 1 are plotted in Fig. 2; the lines in this figure are a least-squares $f i t$ of the data. As can be seen in this figure, for passivation times less than $6 \mathrm{~s}$, the facing-upward and facing-downward anodes have similar correlation between passivation times and current densities; however, for passivation times longer than $6 \mathrm{~s}$, a facing-downward anode has a longer passivation time at a given current density. This figure also shows that the presence of zincate in the electrolyte shortens the passivation time.

Table 2 lists the passivation times of facing-upward anodes discharged at a wide range of current densities in three different concentrations of $\mathrm{KOH}(0.784,2.92$, and $4.98 \mathrm{M}) ; \mathrm{Fig} \cdot 3$ shows these data in graph form as well 
Table 1... Galvanostatic Polarization of Zinc Anodes in $7.24 \mathrm{M} \mathrm{KOH} \cdot$ Electrolytes at Room Temperature $\left(20^{\circ} \mathrm{C}\right)$

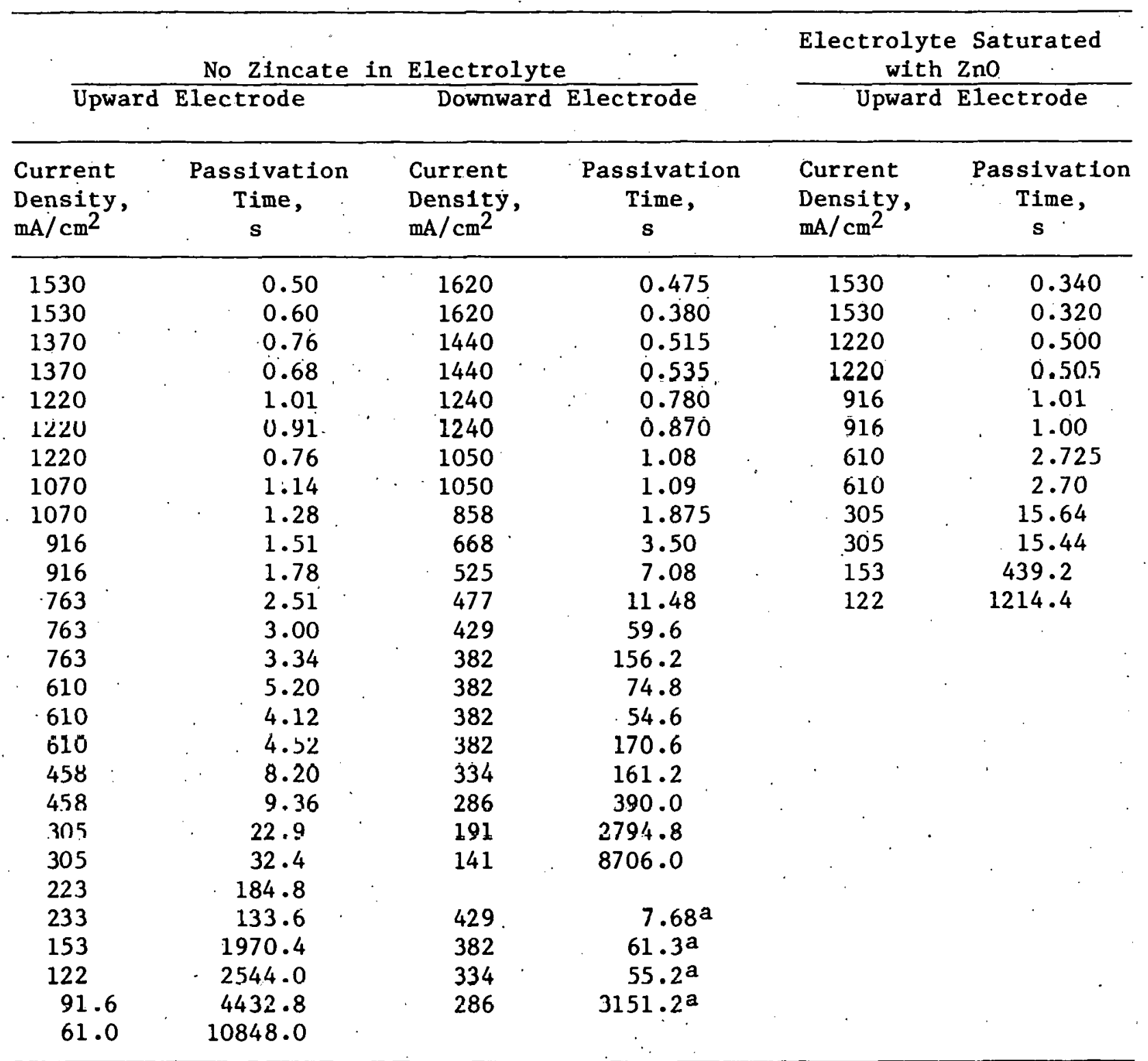

${ }^{a}$ A 1-mm deep channel has been created by chemical etching before the polarization was measured.

as the data from the facing-upward anode in $7.24 \mathrm{M} \mathrm{KOH}$ from Fig. 2. As can be seen in this figure, a higher, concentration of $\overline{K O H}$ will result in a longer passivation time for a zinc electrode at a given current density; therefore, a high concentration of $\mathrm{KOH}$ should result in increased zinc electrode lifetime.

Using the data from Tables 1 and 2, we determined the correlation constants of Eq. $2\left(k, i_{e}\right)$ for zinc microelectrodes in the $\mathrm{KOH}$ electrolyte; the 


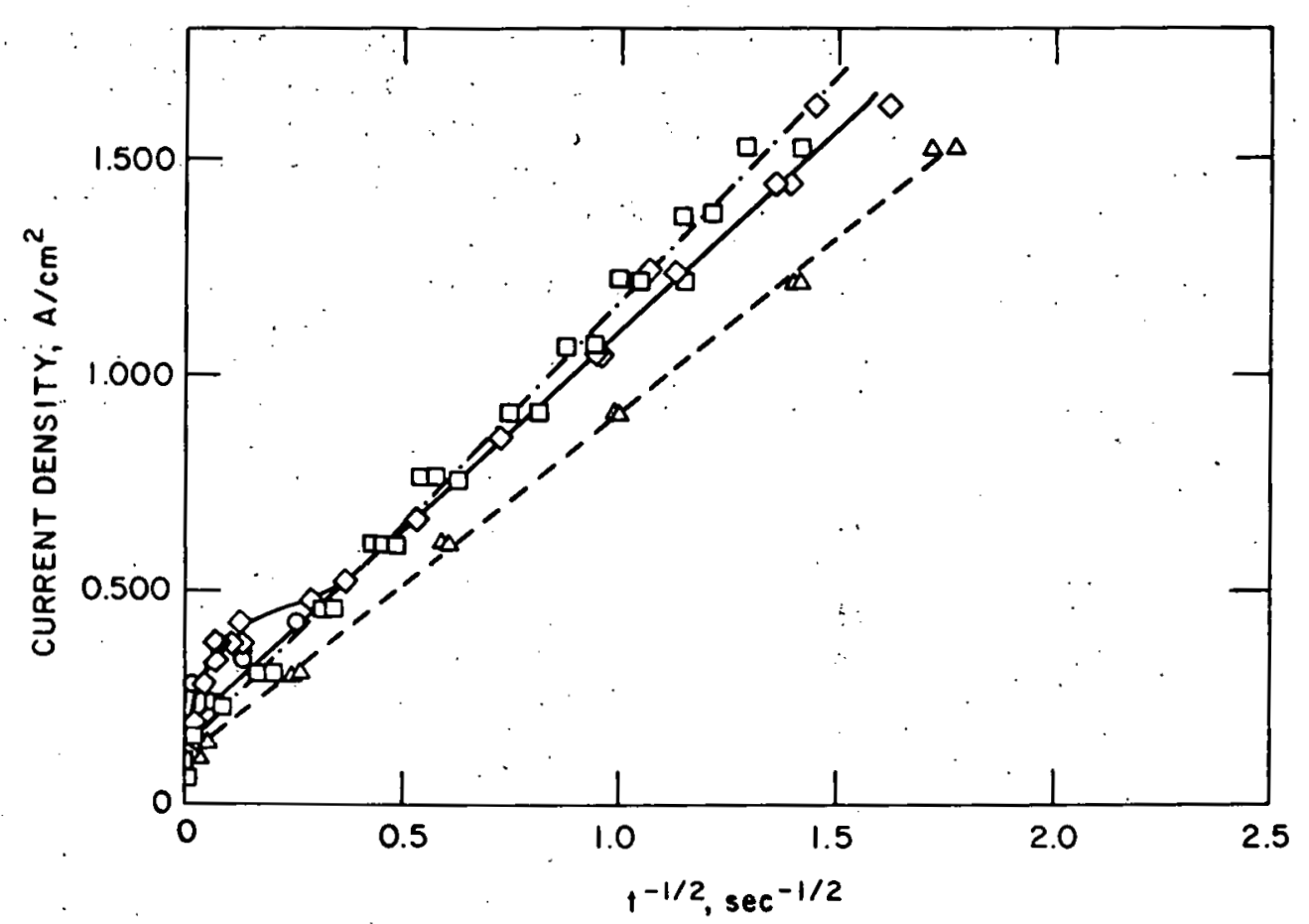

Fig. 2. Current Density vs. Passivation Time of the Zinc. Anode in $7.24 \mathrm{M} \mathrm{KOH}$ (squares, upward anode; diamonds, downward anode; circles, downward anode with $1-\mathrm{mm}$ plastic channel; triangles, upward anode and saturated with zincate)

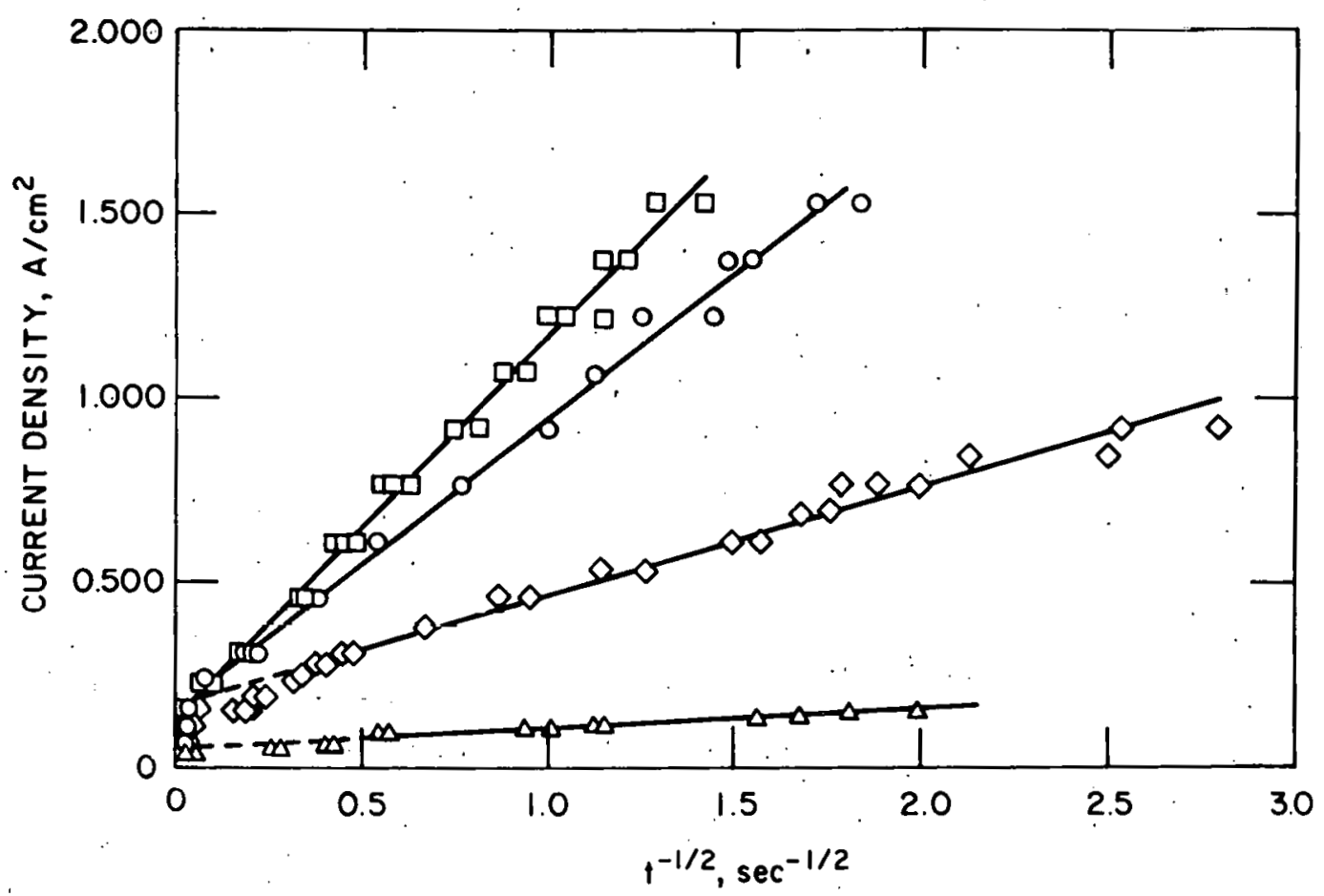

Fig. 3. Current Density vs. Passivation Time for Facing-Upward Anode in $7.24 \mathrm{M}$ (squares), 4.98M (circles), $2.92 \mathrm{M}$ (diamonds), and $0.784 \underline{\mathrm{M}}$ (triangles) $\mathrm{KOH}$ Electrolyte. 
Table 2. Galvanostatic Polarization of the Facing-Upward Zinc Anodes in Three Concentrations of $\mathrm{KOH}$ Electrolyte at Room Temperature $\left(20^{\circ} \mathrm{C}\right)$

\begin{tabular}{|c|c|c|c|c|c|}
\hline \multicolumn{2}{|c|}{$4.98 \mathrm{M} \mathrm{KOH}$} & \multicolumn{2}{|c|}{$2.92 \underline{\mathrm{M}} \mathrm{KOH}$} & \multicolumn{2}{|c|}{$0.784 \mathrm{M} \mathrm{KOH}$} \\
\hline $\begin{array}{l}\text { Current } \\
\text { Density, } \\
\mathrm{mA} / \mathrm{cm}^{2}\end{array}$ & $\begin{array}{c}\text { Passivation } \\
\text { Time, } \\
s\end{array}$ & $\begin{array}{l}\text { Current } \\
\text { Density, } \\
\mathrm{mA} / \mathrm{cm}^{2}\end{array}$ & $\begin{array}{c}\text { Passivation } \\
\text { Time, } \\
\text { s }\end{array}$ & $\begin{array}{l}\text { Current } \\
\text { Density, } \\
\mathrm{mA} / \mathrm{cm}^{2}\end{array}$ & $\begin{array}{l}\text { Passivation } \\
\text { Time, } \\
\text { s }\end{array}$ \\
\hline 1530 & 0.30 & 916 & 0.128 & 153 & 0.305 \\
\hline 1530 & 0.338 & 916 & 0.156 & 153 & 0.250 \\
\hline 1370 & 0.46 & 839 & 0.160 & 137 & 0.410 \\
\hline 1370 & 0.42 & 839 & 0.223 & 137. & 0.355 \\
\hline 1220 & 0.48 & 763 & 0.315 & 122 & 0.760 \\
\hline 1220 & 0.64 & 763 & 0.283 & 122 & 0.780 \\
\hline 1070 & 0.78 & 763 & 0.253 & 107 & $0.980^{\circ}$ \\
\hline $10 / 0$ & U.8US & $68 /$ & 0.355 & 101 & 1.13 \\
\hline 916 & 0.99 & 687 & 0.325 & 91.6 & 1.70 \\
\hline 763 & 1.7 .0 & 610 & 0.450 & 91.6 & 1.85 \\
\hline 1610 & 3.4 & 610 & 0.405 & 76.3 & 3.25 \\
\hline 458 & 7.06 & 534 & 0.665 & 76.3 & 3.03 \\
\hline 458 & 8.30 & 534 & 0.770 & 61.0 & 5.40 . \\
\hline 305 & 24.4 & 458 & 1.110 & 61.0 & 5.50 \\
\hline 229 & 176.0 & 458 & 1.320 & 45.0 & 14.02 \\
\hline 153 & 979.2 & 382 & 2.225 & 45.0 & 12.95 \\
\hline 122 & 1673.0 & 382 & 2.400 & 30.5 & 872.4 \\
\hline 91.6 & 3705.6 & 305 & 4.40 & 30.5 & 1464.0 \\
\hline 61.0 & 8448.0 & 305 & 4.75 & & \\
\hline & & 275 & 6.10 & & \\
\hline & & 275 & 5.85 & & \\
\hline & & 244 & 8.66 & & \\
\hline & & 244 & 9.68 & . & \\
\hline & & 229 & 22.28 & & \\
\hline$\therefore$ & . & 191 & 16.12 & & \\
\hline & & 191 & 29.0 & & \\
\hline & & 153 & $44: 2$ & & \\
\hline & & 153 & 29.4 & & \\
\hline & & 153 & 29.2 & . & \\
\hline & & 122 & 745.2 & & \\
\hline$:$ & & 122 & 689.2 & . & · \\
\hline & & 91.6 & 2325.6 & & \\
\hline$:$ & & 61.0 & 6240 & & \\
\hline
\end{tabular}

results are shown in Table 3. Table 1 shows that, for the facing-upward anode in $7.24 \mathrm{M} \mathrm{KOH}$, the passivation times were significantly longer at current densities $\leq 153 \mathrm{~mA} / \mathrm{cm}^{2}$. Therefore, in Table 3, correlation constants for this 
Table 3. The Correlation Constants $\left(i=k t^{-1 / 2}+i_{e}\right)$ of the $\mathrm{Zinc}$ Anodes

\begin{tabular}{|c|c|c|c|c|}
\hline \multirow[b]{2}{*}{$\begin{array}{l}\text { Electrode } \\
\text { Orientation }\end{array}$} & \multirow[b]{2}{*}{ Electrolyte, $\underline{M}$} & \multirow{2}{*}{$\begin{array}{l}\text { Current } \\
\text { Density } \\
\text { Range, } \\
\mathrm{mA} / \mathrm{cm}^{2}\end{array}$} & \multicolumn{2}{|c|}{ Correlation Constants } \\
\hline & & & $\mathrm{k}, \mathrm{l} / 2 / \mathrm{cm}^{2}$ & $i_{\mathrm{mA} / \mathrm{cm}^{2}}$ \\
\hline Upwarda & 7.24 & $\begin{array}{c}200-1530 \\
60-153\end{array}$ & $\begin{array}{l}1.03( \pm 0.02) \times 10^{3} \\
6.86( \pm 0.70) \times 10^{3}\end{array}$ & $\begin{array}{l}1.32( \pm 0.19) \times 10^{2} \\
-8.05( \pm 12.15)\end{array}$ \\
\hline Downward ${ }^{a}$ & 7.24 & $625-1620$ & $9.23( \pm 0.49) \times 10^{2}$ & $1.86( \pm 0.57) \times 10^{2}$ \\
\hline $\begin{array}{l}\text { Upward and } \\
\text { Downward }\end{array}$ & 7.24 & $525-1620$ & $9.48( \pm 0.30) \times 10^{2}$ & $1.88( \pm 0.30) \times 10^{2}$ \\
\hline Upwarda & $\begin{array}{l}7.24 \\
\text { (Saturated } \\
\text { with } \mathrm{ZnO} \text { ) }\end{array}$ & $\begin{array}{c}200-1530 \\
0-122\end{array}$ & $\begin{array}{l}8.06( \pm 0.11) \times 10^{2} \\
4.25 \times 10^{3}\end{array}$ & $\begin{array}{c}1.08( \pm 0.13) \times 10^{2} \\
0\end{array}$ \\
\hline Upward ${ }^{b}$ & 4.98 & $\begin{array}{c}200-1530 \\
60-153\end{array}$ & $\begin{array}{l}7.79( \pm 0.18) \times 10^{2} \\
4.26( \pm 0.22) \times 10^{3}\end{array}$ & $\begin{array}{l}1.69( \pm 0.20) \times 10^{2} \\
1.77( \pm 0.50) \times 10^{1}\end{array}$ \\
\hline Upward b & 2.92 & $\begin{array}{r}300-916 \\
60-122\end{array}$ & $\begin{array}{l}2.91( \pm 0.09) \times 10^{2} \\
2.32( \pm 0.29) \times 10^{3}\end{array}$ & $\begin{array}{l}1.76( \pm 0.14) \times 10^{2} \\
3.64( \pm 0.85) \times 10^{1}\end{array}$ \\
\hline Upwardb & 0.784 & $60-153$ & $5.41( \pm 0.35) \times 10^{1}$ & $5.18( \pm 0.44) \times 10^{1}$ \\
\hline
\end{tabular}

acorrelation constants determined from data in Table 2 .

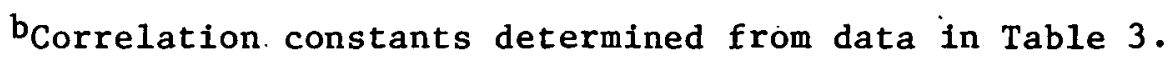

electrode-electrolyte system are given for two current density regions--above and below $153 \mathrm{~mA} / \mathrm{cm}^{2}$. For similar reasons, the correlation constants for facing-upward anodes in $7.24 \mathrm{M} \mathrm{KOH}$ saturated with $\mathrm{ZnO}, 4.98 \mathrm{M} \mathrm{KOH}$, and $2.92 \mathrm{M} \mathrm{KOH}$ are given in two separate current density regions. Since insufficient data were collected, correlations were given for only one current region in the. cases of a facing-downward anode with $7.24 \mathrm{M} \mathrm{KOH}$ electrolyte and a facingupward anode with $0.784 \mathrm{M} \mathrm{KOH}$ electrolyte. The correlation constant given for the low current region of the facing-upward anode with $7.24 \mathrm{M} \mathrm{KOH}$ saturated with Zno was calculated from the datum at $122 \mathrm{~mA} / \mathrm{cm}^{2}$, assuming zero intercept of the $i$ vs. $t^{-1 / 2}$ curve.

\section{DISCUSSION AND CONCLUSIONS}

A. One-Dimensional Diffusion Model.

To justify the validity of Eq. 2, Dirkse and Hampson 13 proposed a onedimensional diffusion model in which the accumulation of zincate ions at the electrode surface is the determining step of passivation. However, for an 
electrode reaction controlled by; a diffusional mass transport; the onedimensional model.is valld only if the following three factors are minimal: mass transfer by convection of zincate ion induced by the net changes of volume due to the electrochemical and chemical reactions, 30 migration, and three-dimensional diffusion. The following discussion shows that the se three mass transport mechanisms can indeed be neglected for passivation times less than $14 \mathrm{~s}$.

For the anodic reaction of the zinc electrode (see reaction 1 ), the net change of volume in the solid electrode and in the species in the electrolyte induces a superficial average velocity for the electrolyte, which is given by the equation, 31

$$
v^{\square}=\frac{-i}{n F}\left[\bar{V}_{Z n}+4 \bar{V}_{B}-\bar{v}_{A}-2\left(t_{2}{ }^{\circ} V_{A}+t_{3} \bar{V}_{B}\right)\right]
$$

where $\overline{\mathrm{V}}_{\mathrm{Zn}}, \overline{\mathrm{V}}_{\mathrm{A}}$, and $\overline{\mathrm{V}}_{\mathrm{B}}$ are the partial molar volumes of zinc, potassium zincate, and potassium hydroxide, respectively; and $t_{2}^{\circ}$ and $t_{3}^{\circ}$ are the transference numbers of zincate and hydroxide ions, respectively. A v of $-1.5 \times 10^{-4} \mathrm{~cm} / \mathrm{s}$ was obtained by substituting into $\mathrm{Eq} \cdot 5$ data given by Sunu ${ }^{31}--\overline{\mathrm{V}}_{\mathrm{Zn}}, 9.15 \mathrm{~cm}^{3} / \mathrm{mul}$; $\bar{V}_{A}, 67.0 \mathrm{~cm}^{3} / \mathrm{mol} ; \bar{V}_{B}, 17.8 \mathrm{~cm}^{3} / \mathrm{mol} ; t_{2}, 0.05 ;$ and $t_{3}^{\circ}, 0.72--$ and a current density of $1.53 \mathrm{~A} / \mathrm{cm}^{2}$. (The negative sign of the value for $\mathrm{v}^{\mathrm{m}}$ means that the flow is in the direction opposite to the electrode surface.) When. $v^{D}$ is included, the one-dimensional mass transfer equation becomes

$$
\frac{\partial C}{\partial t}+v^{\square} \frac{\partial C}{\partial x}=n \frac{\partial^{2}}{\partial x^{2}}
$$

where $C$ is the concentration of zincate ion, $D$ is the diffusion coefficient of zincate Ion, and $x$ is the distance from the electrode surface.. No analytical solution of Eq. 6 can be obtained for the present system. However, when $\mathrm{v}^{\mathrm{D}}$ is considered as a perturbation of a one-dimensional diffusion, the solution to Eq. 6 can be approximated as

$$
c_{c r i t}-c_{b}=\left(\frac{i}{F}\right)\left[\left(\frac{\mathrm{t}}{\mathrm{D}}\right)^{1 / 2}+\left(\frac{\mathrm{v}}{2 \mathrm{D}}\right) \mathrm{t}\right]
$$

Numerical calculations indicate that $\dot{v}^{\square}$ could account for only $5 \%$ of the time controlled by a diffusion process. Thus, convection induced by the net change in volume of the solid electrode and electrolyte is minimal.

The possibility of three-dimensional diffusion must be considered since small electrodes were used to achieve uniform current density in our study. A three-dimensional diffusion in an isotropic medium takes the form of

$$
\frac{\partial C}{\partial t}=D\left(\frac{\partial^{2} C}{\partial r^{2}}\right)+\frac{2}{r}\left(\frac{\partial C}{\partial r}\right)
$$


where $r$ is the radial coordinate of a spherical geometry. With the proper initial and boundary conditions, one can show that the solution of Eq. (8) can be written as:

$$
C_{c r i t}-C_{b}=\frac{i}{n F}\left(\frac{a}{D}\right) \cdot\left[1-\exp \left(\frac{D t}{a^{2}}\right) \operatorname{erfc}\left(\frac{D t}{a}\right)\right]
$$

where the error function, $\operatorname{erfc}(x)$, is defined as

$$
\operatorname{erfc}(x)=1-\operatorname{erf}(x)=\frac{2}{\sqrt{\pi}} \int_{x}^{\infty} e^{-x^{2}} d x
$$

and $a$ is the radius of a spherical electrode. For a small value of (Dt) $1 / 2 / a$ $(\mathrm{e} . \mathrm{g} \cdot, 0.2)$, the bracket term in Eq. 9 can be approximated as $2(\mathrm{Dt} / \pi)^{1 / 2 / a ;}$ and therefore can be rearranged to $\mathrm{Eq}$. 3. . If the electrode surface can be approximated as a semisphere with a base area equal to the surface area of the electrode $\left(6.5 \times 10^{-3} \mathrm{~cm}^{2}\right)$, then a is calculated to be $4.5 \times 10^{-2} \mathrm{~cm}$. With this. value of $a, D=6 \times 10^{-6} \mathrm{~cm}^{2} / \mathrm{s}, 32$ and $(D t)^{1 / 2} / \mathrm{a}=0.2$; we obtain a value of passivation time of $14 \mathrm{~s}$ below which the one-dimensional diffusion model is valid.

If mass transfer of zincate by migration is incorporated into the diffusion model, the current density, $i$, is multiplied by a factor of one plus $t_{2}$. Since the size of zincate ion is relatively large compared with the sizes of potassium and hydroxide ions, the transference number of zincate ion is expected to be small (Sunu ${ }^{31}$ gave a value of 0.05 ). Therefore; the effect on passivation time of mass transfer of zincate ions by migration is minimal.

Since the effects of mass transfer of zincate ions by convection, migration, and three-dimensional diffusion are minimal for passivation times below $14 \mathrm{~s}$, the value of $i_{e}$ in Eq. 2 should be zero, and a combination of Eqs. 2 and 3 yields

$$
\mathrm{k}=\left(\mathrm{C}_{\text {crit }}-\mathrm{C}_{\mathrm{b}}\right) \cdot \mathrm{nF}\left(\frac{\pi \mathrm{D}}{4}\right)^{1 / 2}
$$

The calculated values of $\mathrm{k}$ using Eq. 11 are compared with the values obtained from our experimental data in Table 4. Although the calculated values of $k$ are from 0.86 to 1.49 times the experimental values, the values of $i_{e}$ given in Table 3 are not zero. This discovery will be discussed later; however, before we do so, we will compare our results with those of previous studies.

\section{B. Comparison with Previous Studies}

The linear increase of potential with time before the onset of passivation of our zinc microanodes is shown in. Fig. $4 \mathrm{a}$ for a current density of $1.22 \mathrm{~A} / \mathrm{cm}^{2}$ and Fig. $4 \mathrm{~b}$ for $0.61 \mathrm{~A} / \mathrm{cm}^{2}$. This effect was also observed by Dirkse and Hampson:13 The overpotential increase may be mainly due to increases in the 
Table 4. Comparison of the Experimental Values of Correlation Constants (k)

\begin{tabular}{|c|c|c|c|c|c|c|}
\hline \multirow{2}{*}{$\begin{array}{l}\text { Electrode } \\
\text { Orientation }\end{array}$} & \multirow{2}{*}{$\begin{array}{c}\text { Concentration } \\
\text { of } \mathrm{KOH}, \underline{M}\end{array}$} & \multirow{2}{*}{$\begin{array}{l}\text { Diffusion } \\
\text { Coefficient } \\
\text { of Z1ncate } \\
\text { Ion, a } \\
\mathrm{cm}^{2} / \mathrm{s}\end{array}$} & \multirow{2}{*}{$\begin{array}{l}\text { "Critical" } \\
\text { Concentration } \\
\text { of Z1ncate } \\
\text { 1on, } b \underline{M}\end{array}$} & \multirow{2}{*}{$\begin{array}{c}\text { Bulk } \\
\text { Concentration } \\
\text { of Zincate } \\
\text { Ion, } \underline{M}\end{array}$} & \multicolumn{2}{|c|}{$\begin{array}{l}\dot{\mathrm{mA}-\mathrm{s}} 1 / 2 / \mathrm{cm}^{2} \\
\text { Correlation }\end{array}$} \\
\hline & & & & & Experimental & $\mathrm{Eq} \cdot 11$ \\
\hline Upward & 7.24 & $6 \times 10^{-6}$ & 2.3 & $\underline{0}$ & $1.03( \pm 0.02) \times 10^{3}$ & $9.64 \times 10^{2}$ \\
\hline Downward & 7.24 & $6 \times 10^{-6}$ & 2.3 & 0 & $9.23( \pm 0.49) \times 10^{2}$ & $9.64 \times 10^{2}$ \\
\hline Upward & $\begin{array}{l}7.24 \text { sat'd } \\
\text { w1th Zno }\end{array}$ & $6 \times 10^{-6}$ & 2.3 & 0.64 & $8.06( \pm 0.11) \times 10^{2}$ & $6.95 \times 10^{2}$ \\
\hline Upward & 4.98 & $8 \times 10^{-6}$ & 1.4 & 0 & $7: 79( \pm 0.18) \times 10^{2}$ & $6.77 \times 10^{2}$ \\
\hline Upward & 2.92 & $1.0 \times 10^{-5}$ & 0.8 & $\mathbf{0}$ & $2.91( \pm 0.09) \times 10^{2}$ & $4.33 \times 10^{2}$ \\
\hline Upward & 0.784 & $1.2 \times 10^{-3}$ & 0.1 & 0 & $3.41( \pm 0.35) \times 10^{1}$ & $3.99 \times 10^{1}$ \\
\hline
\end{tabular}

Data based upon information in Ref. 32 .

bata based upon information in Ref. 33 .

ohmic resistance of the system. The short-life transition preceding the onset of passivation of zinc electrodes at the low current density (Fig. 4b) has also been observed by Bartelt and Landsberg 7 and Elder.12 Since the electrode potential at the transition is in the vicinity of the $\mathrm{Zn} / \mathrm{ZnO}$ standard potential, the transition may be associated with the direct formation of the passivating type II Zno film observed by Powers et al.17

Although Hampson et a1.8,11,13 have claimed that no evidence could be found for any change in slope of the $i$ vs. $t^{-1 / 2}$ curves as observed earlier by: Landsberg and Bartelt, 5 our results (Figs. 2 and 3 ) indicate that there are upper and lower current density regions, each of which has a different correlation constant (see Table 3 ) for the facing-upward anodes. Hampsun et $a 1.8,11,13$ and. Eisenberg et a1.6 reported that $1_{e}$ in Eq. 2 is associated with natural convection. If this were true, extrapolation of the data obtained in the high current-density region would yield intercepts at zero, but the data in Figs. 2 and 3 contradict this assumption.

Yamashita et a1.14 measured the optical phase shift on a zinc electrode during a constant current discharge. They concluded that, at the first major phase shift, the electrolyte at the electrode surface becomes saturated with zincate and type I zinc oxide.film begins to form and grow on: the anode, and that, at the second major phase shift, the electrode becomes fully covered by compact type II zinc oxide film and thus passivated. Using ellipsometry and 
(a)

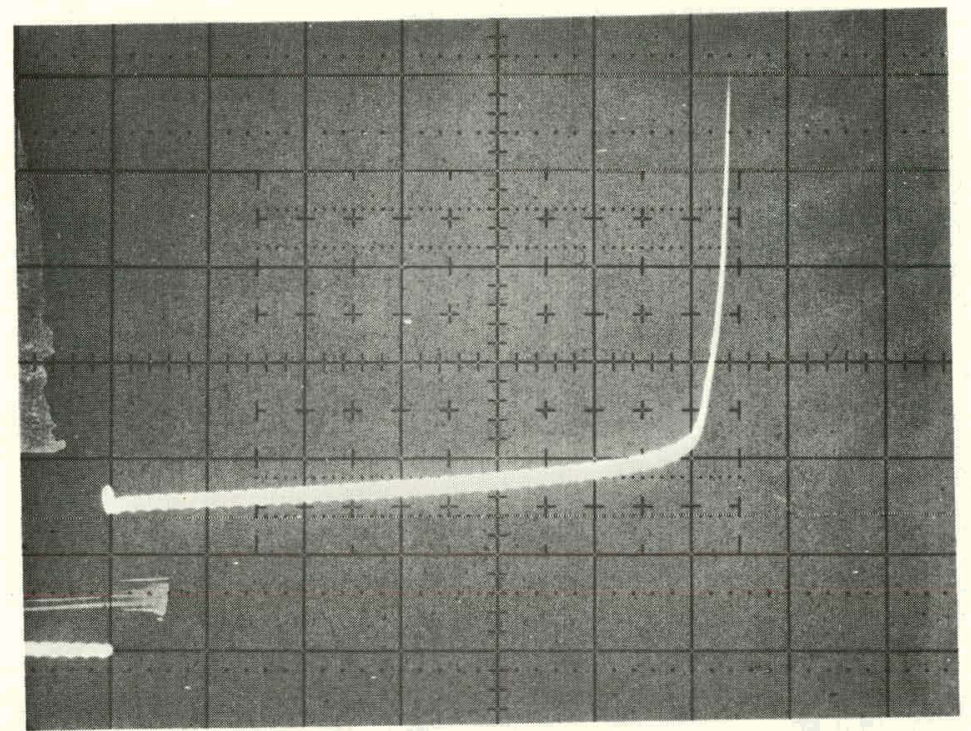

$i=1.22 \mathrm{~A} / \mathrm{cm}^{2}$ ( $\mathrm{Y}$-axis, $0.1 \mathrm{~V} /$ division; $\mathrm{X}$-axis, $0.1 \mathrm{~s} /$ division)

(b)

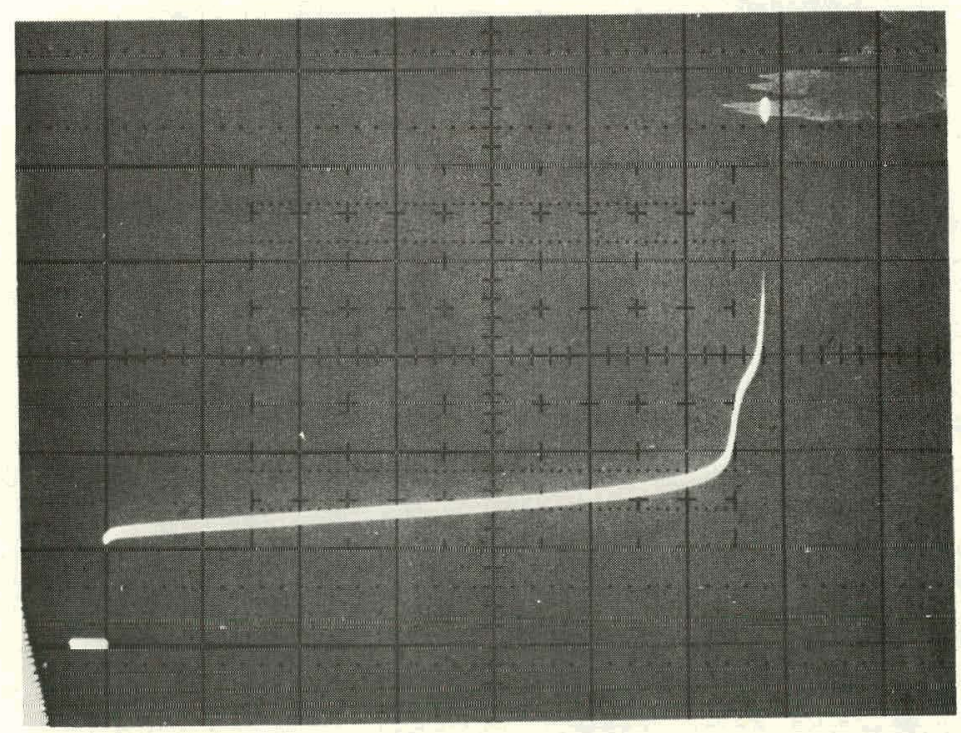

$$
\begin{aligned}
i= & 0.61 \mathrm{~A} / \mathrm{cm}^{2} \text { ( } \mathrm{Y} \text {-axis, } 0.1 \mathrm{~V} / \text { division; } \\
& \mathrm{X} \text {-axis, } 0.5 \mathrm{~s} / \text { division) }
\end{aligned}
$$

Fig. 4 Chronopotentiograms of Zinc Microanodes (4.98ㅆ KOH, Facing-Upward). 
scanning electron microscopy, Smith has studied the anodic film growth of silver oxide, zinc oxide, and cadmium oxide under stagnant and forced convection conditions. He concluded that the process of anodic film growth of zinc oxide begins with roughening of the metal substrate and the growth of a mass transfer boundary layer, then the formation of "primary films," and finally passivation by a "compact primary layer" (porosity, about 0.003). This process is not in agreement with the hypothesis of Hampson et a1.,8,11,13 who have stated that passivation occurs when $\mathrm{C}_{\text {crit }}$ of zincate is established in the layer of electrolyte in contact with the electrode surface. We subsequently calculated the passivation times by substituting into Eq. 3 the diffusion coefficient data of zincate given by McBreen and Cairns 32 and the solubility limit of zincate (equal to half of bulk $\mathrm{OH}^{-}$concentration as assessed by Hampson et al.11,34). This calculation resulted in passivation times that were on $1 \mathrm{y}$ $\overline{1.5-8} .4 \%$ of those given in Tables 1 and 2 for the low current density region. Therefore, the hypothesis of Hampson et al. does not explain our data.

It is generally postulated that passivation occurs when a "critical" concentration of zincate, usually three times chemical saturation, is established in the layer of electrolyte in contact with the elertrode surface.10,13 Since the density of a $\mathrm{KOH}$ electrolyte increases with increasing zincate content, natural convection can easily develop at the vicinity of the surface of a facing-downward electrode when the passivation time is less than one minute.35 The facing-upward anode should effectively suppress this natural convection since the anode can hold zincate ions. Therefore, a divergence in the passivation times for the electrodes of these two orientations in $7.24 \mathrm{M} \mathrm{KOH}$ occurs when the passivation time is longer than $6 \mathrm{~s}$ (see Fig. 2). The data in Table 1 for the facing-downward electrode with a plastic channel of 1 -mm depth indicate that natural convection has heen reduced to a certain extent, but not completely, by the shear stress exerted by the plastic channel wall.

\section{PROPOSED ANODIC YROCESSES OF ZINC}

In order to explain our experimental data, we propose the following scheme, shown in Fig. 5, for the processes associated with the anodic passivation of zinc in alkaline solutions. In the first step, the anodic reaction yields zincate, which accumulates near the electrode surface since diffusion is not fast enough to dissipate the newly formed zincate. In the next step, the accumulation of zincate results in a $\mathrm{C}_{\text {crit }}$ at which the rate of formation of type I film through a precipitation and dissolution mechanism becomes appreciable. The time at which $\mathrm{C}_{\text {crit }}$ is achieved, $\mathrm{t}_{\mathrm{a}}$, can be estimated by using Eq. 3, provided that $\mathrm{D}$ and $\mathrm{C}_{\mathrm{crit}}$ are known. The value of $\mathrm{C}_{\text {crit }}$ is believed to be a factor of three to four times the solubility of $\mathrm{ZnO}$ in $\mathrm{KOH}$ solution and has an upper limit equal to half of the bulk $\mathrm{OH}^{-}$concentration; 11,13,14,34,36,37 $\mathrm{C}_{\text {crit }}$ will be the same whether in a zinc oxide saturated solution or an electrolyte initially free from zincate. 37 In Eq. 3, the term $C_{c r i t}-C_{b}$ implies that the presence of zincate in the electrolyte shortens the passivation time; our results confirm this (see Table 1 and Fig. 2) conjecture. However, it is very difficult to detect on chronopotentiograms the time at which $\mathrm{C}_{\text {crit }}$ occurs, unless other means, such as an ellipsogram, are made available. The transformation of zincate to zinc oxide (type I) and mass transport of $\mathrm{OH}^{-}$ions through 


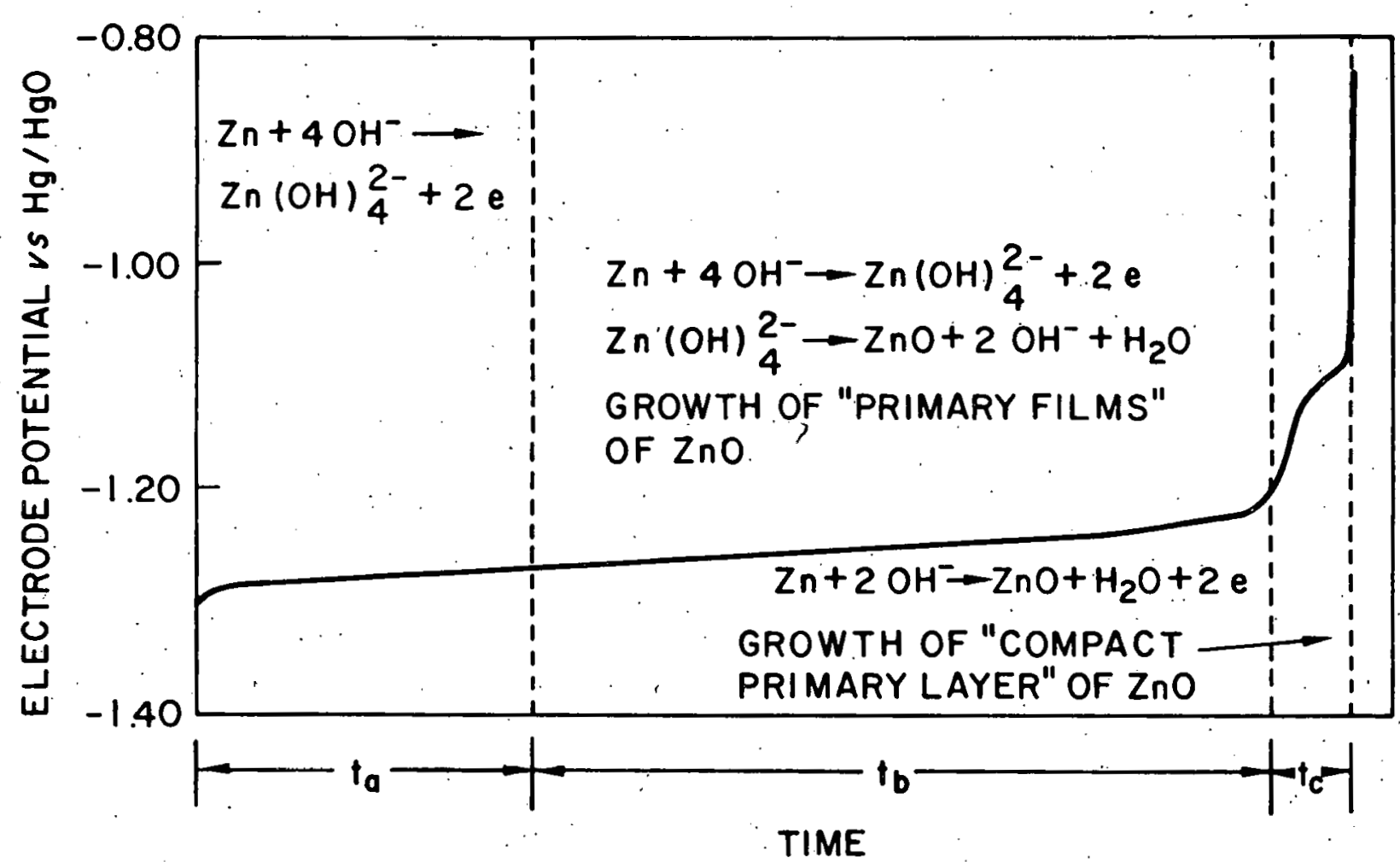

Fig. 5. Proposed Scheme for the Processes Associated with the Anodic Passivation of Zinc in Alkaline Solutions.

this porous zinc oxide 17 permit the continuation of the electrode reaction. After the passage of another period of time, $t_{b}$, the electrode potential reaches the vicinity of -1.20 volts $\mathrm{vs}$. $\mathrm{Hg} / \mathrm{HgO}$, which is approximately the $\mathrm{Zn} / \mathrm{ZnO}$ standard potential; 17,38 at this point, formation of zinc oxide (type II) is initiated on the electrode surface. In the final period of time, $t_{c}$, the electrode surface is totally covered by this compact type II Zno, limiting the transport of $\mathrm{OH}^{-}$ions. In this manner, the electrode becomes passivated. This proposed mechanism agrees with the observation of anodic film growth of zinc oxide by Smith using ellipsometry and a scanning electron microscope. 33

According to the proposed mechanism, the passivation time can be expressed by the equation:

$$
t=t_{a}+t_{b}+t_{c}
$$

where $t_{a}$ is the time at which $C_{c r i t}$ is established, and $t_{b}$ and $t_{c}$ are the times during which type I and type II Zno films, respectively, are formed: Yamashita et al.14 were the first to use the chronoellipsometry method to determine $t_{a}, t_{b}$, and $t_{c}$. Figure 6 shows $t, t_{a}$, and $t_{b}$ plus $t_{c}$ at different current densities for the zinc anodes (area, $2.1 \mathrm{~cm}^{2}$ ) in $2.8 \mathrm{M} \mathrm{KOH}$ tested by 


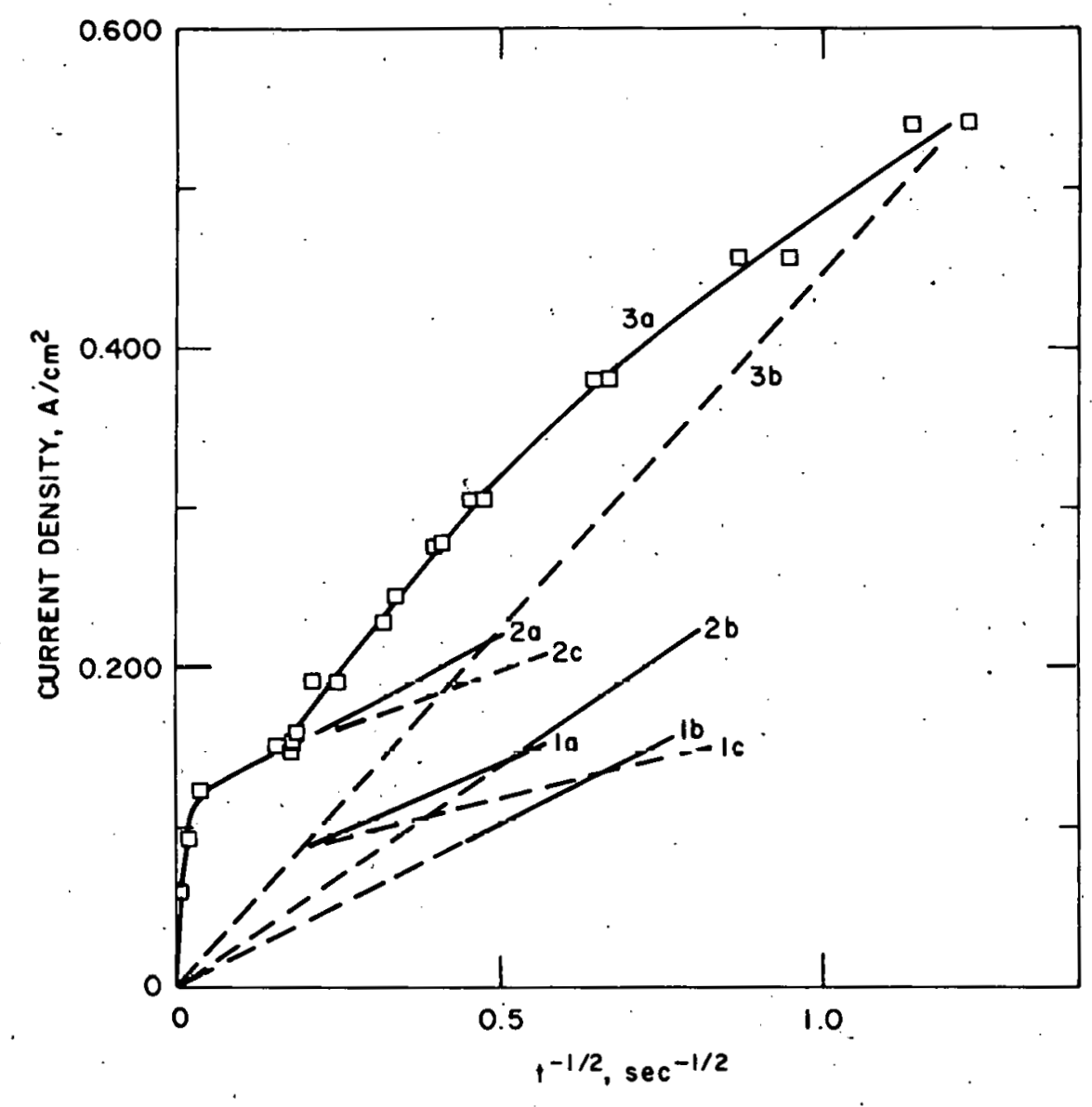

\begin{tabular}{|c|c|c|c|c|}
\hline $\begin{array}{c}\text { KOII } \\
\text { Concentration, } \\
\underline{M}\end{array}$ & $\begin{array}{l}\text { Diffusion: } \\
\left(L_{a}\right)\end{array}$ & $\begin{array}{l}\text { Growth of } \\
\text { Type I and II } \\
\text { Zno Films } \\
\left(t_{b} \text { and } t_{c}\right)\end{array}$ & $\begin{array}{l}\text { Overali } \\
\text { Passivation } \\
\text { Time } \\
\text { (t) }\end{array}$ & Reference \\
\hline $\begin{array}{l}2.0 \\
2.8 \\
2.93\end{array}$ & $\begin{array}{l}1 b \\
2 b \\
3 b\end{array}$ & $\begin{array}{l}1 c \\
2 c \\
-\end{array}$ & $\begin{array}{l}1 a \\
2 a \\
3 a\end{array}$ & $\begin{array}{c}14 \\
14 \\
\text { thie Work }\end{array}$ \\
\hline
\end{tabular}

Fig. 6. Current Density vs. Passivation Times for Zinc Anodes $\left(2.1 \mathrm{~cm}^{2}\right.$ ) in 2.0 and $2.8 \mathrm{M} \mathrm{KOH} \mathrm{(Experiment} \mathrm{Conducted}$ by Yamashita et a1.14)

Yamashita et al. For this figure, $t_{a}$ and $t$ represent experimentally measured values; $t_{b}$ plus $t_{c}$ was then easily determined from Eq. 15. Also included in Fig. 6 are our passivation data for the zinc electrode. in $2.92 \mathrm{M} \mathrm{KOH}$; the value of $t_{a}$ for this electrode was generated by substituting the solubility data of electrochemically generated $\mathrm{ZnO}^{36}$ and the diffusion coefficient of zincate 32 into Eq. 3 . Figure 7 shows passivation-time data for one of our 


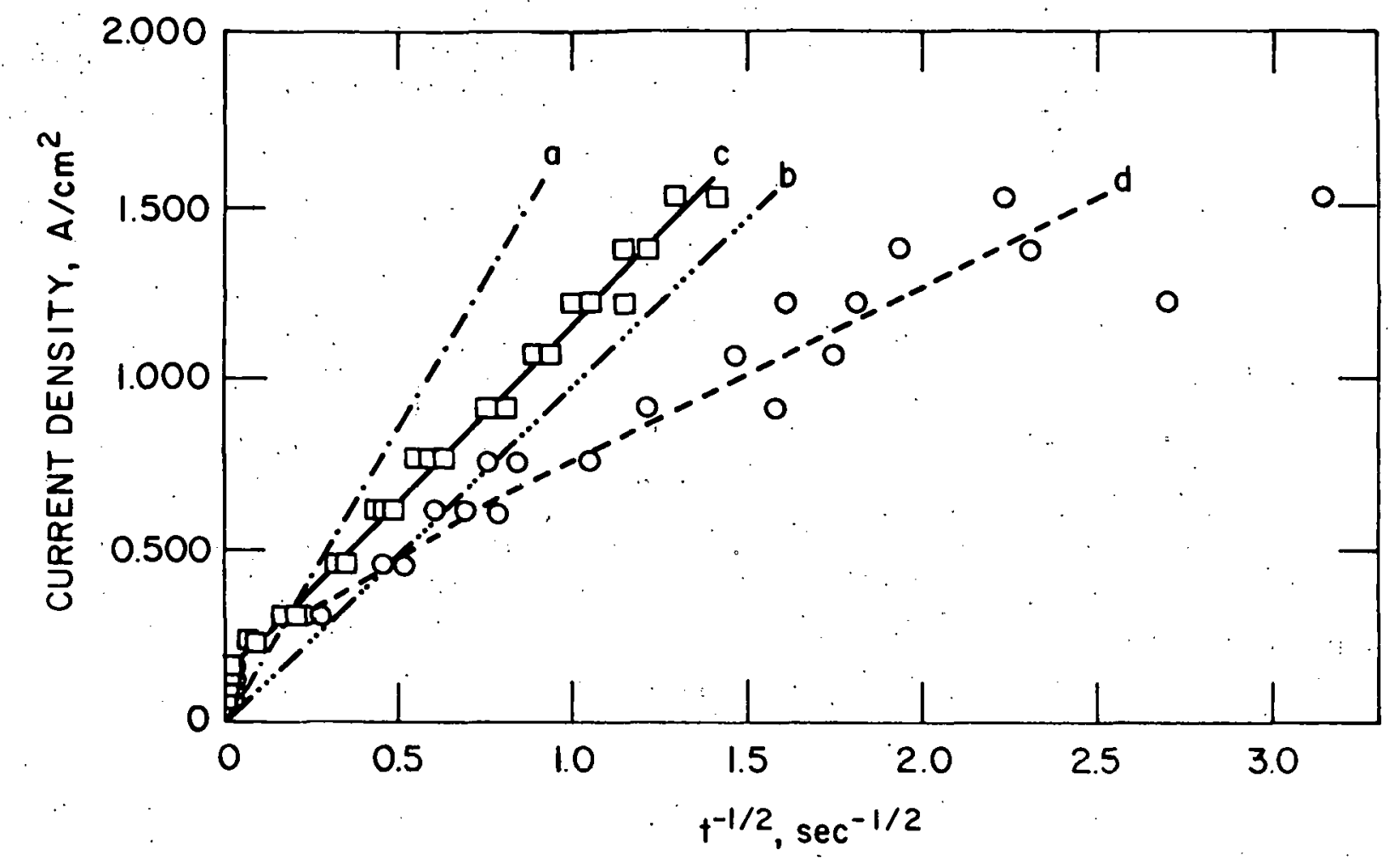

Fig. 7. Current Density vs. Passivation Time for FacingUpward-Zinc Anodes in $7.24 \mathrm{M} \mathrm{KOH} \mathrm{(significance} \mathrm{of}$ the different lines is explained in the text).

facing-upward anodes in $7.24 \mathrm{M} \mathrm{KOH}$. Line (a) represents passivation time caused only by a simple exhaustion of $\mathrm{OH}^{-}$species at the electrode surface and no precipitation; line (b) represents $t_{a}$ and was determined in the same manner as used for Fig. 6; line (c) shows our passivation-time data; and line (d) was derived from lines (c) and (b), 1.e., t $-t_{a}$.

In Figs. 2 and 3, we obtained nonzero intercepts for our data in the region of high current densities because. $t_{a}$ is not the major component of $t$ throughout this region of current densities. However, as shown in Table 3 , the values of $i_{e}$ for the passivation data of the region of low current densities are nearly zero. To explain these results, we propose that the passivation time is almost entirely spent on the anodic film growth of type I $\mathrm{ZnO}$. The electrode passivates because the anodic reaction rates are limited by the transport of $\mathrm{OH}^{-}$lons through this zinc oxide film.33 In our experiments, the zinc electrodes were set in acrylic plastic: The anodic reaction of zinc (reaction 1) erodes the solid zinc and leaves space surrounded by the plastic wall for the growth of the type I $\mathrm{ZnO}$ film. This type I $\mathrm{Zn} 0$ film has pores of about $7500 \AA$ on the average 29 and a porosity of 0.003 to $0.85^{33}$ and, thus, presents a mass transfer resistance to the system. To obtain 
a quantitative description of the effect of mass transfer resistance of the type I $\mathrm{ZnO} \mathrm{film}$, we assumed that, at the electrode surface, the rate of supply of $\mathrm{OH}^{-}$ions is equal to the rate of consumption of $\mathrm{OH}^{-}$. ions by the electrode reaction. Therefore,

$$
\frac{4 i}{n F}=\frac{\varepsilon^{\left(1+t_{e}\right)} D_{3}}{\delta}\left(C_{3 b}-C_{3 s}\right)+\left(\frac{-i t_{3}^{0}}{z_{3} F}\right)+\left(\frac{2 y}{n F}\right) i
$$

where the term in the left-hand side is the consumption rate of $\mathrm{OH}^{-}$ions according to reaction 1 ; and the terms on the right-hand side represent the supply of $\mathrm{OH}^{-}$ions by diffusion, migration, and precipitation of $\mathrm{ZnO}$ (see Fig. 5), respectively. In Eq. $16, \varepsilon$ is the porosity; $t_{e}$ is the tortuosity factor of the $\mathrm{ZnO}$ film; $\mathrm{D}_{3}$ is the diffusion coefficient. of $\mathrm{OH}^{-}$ions; $\mathrm{C}_{3 \mathrm{~b}}$ and $\mathrm{C}_{3 \mathrm{~s}}$ are the concentrations of $\mathrm{OH}^{-}$ions in the bulk electrolyte and at the electrode surface, respectively; $\mathrm{t}_{3}$ and $z_{3}$ are the transterience number and che charge of $\mathrm{OH}^{-}$ions, respectively; $\dot{y}$ is the ratio of the rate of precipitation of $\mathrm{ZnO}$ to that of electrochemical formation of zincate; and $\delta$ is the thickness of mass-transfer.boundary layer (assumed to be equal to the thickness of the $\mathrm{ZnO} \mathrm{film}$ ). The rate of increase in the thickness of the $\mathrm{ZnO}$ fillu can be written as:

$$
\frac{\mathrm{d} \delta}{\mathrm{dt}}=\frac{\overline{\mathrm{V}}_{\mathrm{Zn} 0}}{(1-\epsilon)} \frac{\mathrm{yi}}{\mathrm{nF}}
$$

where $\overline{\mathrm{V}}_{\mathrm{Zn} 0}$ is the partial molar volume of $\mathrm{ZnO}$. Since, in the low current density region, the time required to establish the $\mathrm{C}_{c r i t}$ concentration is negligible compared with the passivation time, we may set $\delta$ equal to zero at $\dot{t}=0$. Thereby, we obtain, the expression:

$$
\delta=\frac{\bar{v}_{7 . n n}}{(1-\varepsilon)} \frac{y i}{n F} \cdot t
$$

Combining Eqs. 16 and 18, we obtain

$$
\frac{\bar{V}_{Z n O}}{(1-\varepsilon)} \frac{y}{n F}\left[\frac{(4-2 y)}{n F}+\frac{t_{3}^{\circ}}{z_{3} F}\right] i^{2} t=\varepsilon^{\left(1+t_{e}\right)} D_{3}\left(C_{3 b}-C_{3 s}\right)
$$

At the time when $\mathrm{C}_{3 \mathrm{~s}}$ is equal to zero; the electrode passivates. Thus, we obtain

$$
i t^{1 / 2}=\left\{\frac{\varepsilon^{\left(1+t_{e}\right)} D_{3} c_{3 b}}{\frac{\bar{v}_{Z n 0}}{(1-\varepsilon)} \frac{y}{n F}\left[\frac{(4-2 y)}{n F}+\frac{t_{3}}{z_{3} F}\right]}\right\}^{1 / 2}
$$

The right side of Eq. 20 represents the correlation constant, $k$ (see Eq. 2), for the low current density region in Table 3 . We may use these data to calculate the porosity of the $\mathrm{ZnO}$ film. It is likely that the value of $\mathrm{y}$ is close 
to unity since the rate of mass transport of $z$ incate ions from the electrode surface through the $\mathrm{ZnO}$ film to the bulk electrolyte is small compared with the rate of electrochemical formation of zincate ions (reaction 1). Using $\mathrm{t}_{\mathrm{e}}=0.5, \mathrm{y}=1, \mathrm{D}_{3}=3 \times 10^{-5} \mathrm{~cm}^{2} / \mathrm{s}(\operatorname{Ref} .31), \overline{\mathrm{v}}_{\mathrm{Zn} 0}=1.4 .51 \mathrm{~cm}^{3} / \mathrm{mol}, \mathrm{t} \xi=0.72$ (Ref. 36); $z_{3}=-1$, and the values of $k$ in Table 4 , we calculated that the porosities of the $\mathrm{ZnO}$ films are 1.3 in $7.24 \mathrm{M} \mathrm{KOH}, 0.08$ in $7.24 \mathrm{M} \mathrm{KOH}$ saturated with $\mathrm{ZnO}, 0.09$ in $4.98 \mathrm{M} \mathrm{KOH}$, and 0.06 in $2 . \overline{9} 2 \mathrm{M} \mathrm{KOH}$. These porosities of the Zno films are within those observed by Smith. 38 At the end of each measurement of passivation time, we also observed a dark film covering the electrode surface. Therefore, we concluded that, in the low current density region, the electrode reaction of $z i n c$ is accompanied by the growth of type I $\mathrm{ZnO} f i l m$, and that the electrode passivates when the oxide film becomes so thick that the rate of mass transfer of $\mathrm{OH}^{-}$ions through the film is less than the rate of demand of $\mathrm{OH}^{-}$ions. for the electrode reaction.

\section{APPLICATION TO BATTERY TECHNOLOGY}

Passivation of the zinc electrode in alkaline batteries should be avoided if a maximum utilization of the electrode is to be achieved. In the Ni/Zn alkaline batteries under development for vehicle propulsion, the electrolyte is typica11y $30 \% \mathrm{KOH}(7 \mathrm{M})$ saturated with $\mathrm{Zn0}$; and the zinc electrode is formed by in-situ electrodeposition of zinc onto the grid. Using the data from our tests, we were able to estimate the effect of passivation on the utilization of the formed zinc electrode in an alkaline battery. However, it should be noted that our experimental cells had excess electrolyte in comparison with a typical Ni/Zn battery, which usually has a limited amount of electrolyte. Therefore, the projections given below should be used with caution. In addition, our results do not take into account the nonuniformity of current density. distribution that occurs on a battery electrode surface.

For our calculations, we assumed that an electrodeposited-zinc porous electrode for a $\mathrm{Ni} / \mathrm{Zn}$ battery cycled at a 2-h rate has a current density of $20 \mathrm{~mA} / \mathrm{cm}^{2}$. Our results given in Table 3 are for planar electrodes. In order to apply these results to a porous electrode, we first assessed the effective interfacial surface area per square centimeter of macroscopic area and then calculated the corresponding current density in a porous electrode.

A knowledge of the structure of zinc electrodeposits is necessary to assess the effective interfacial surface area. Naybour ${ }^{39}$ observed that the deposits were dendritic at $100 \mathrm{~mA} / \mathrm{cm}^{2}$, consisted of layer growths with some granular growths at $20 \mathrm{~mA} / \mathrm{cm}^{2}$, and were mossy or sponge growths at $4 \mathrm{~mA} / \mathrm{cm}^{2}$. The zinc electrode in a typical $\mathrm{Ni} / \mathrm{Zn}$ battery consists of metallic sponge zinc. 40 A zinc porous electrode cycled at a $2-\mathrm{h}$ rate $\left(20 \mathrm{~mA} / \mathrm{cm}^{2}\right)$ has a charge density of $144 \mathrm{c} / \mathrm{cm}^{2}$. From the data of charge density as well as the size and density of sponge deposits given by Naybour, 39 we estimated the porosity of the deposits to be about 0.6 . Using these data and the molar volume of solid zinc 31 $\left(9.15 \mathrm{~cm}^{3} / \mathrm{mol}\right)$, we calculated that the electrode has an average thickness of zinc deposits of $114 \mu \mathrm{m}$. This value of electrode thickness is slightly less than the characteristic reaction penetration depth, $90 \mu \mathrm{m} .41$ Using this characteristic reaction depth rather than the electrode thickness and a specific 
surface area of $300 \mathrm{~cm}^{2} / \mathrm{cm}^{3}, 31$ we obtained an effective interfacial surface area of 2.7 per square centimeter of electrode area. This effective interfacial surface area yields a current density of $7.4 \mathrm{~mA} / \mathrm{cm}^{2}$ in a planar electrode, which corresponds: to $20 \mathrm{~mA} / \mathrm{cm}^{2}$ at the $2-\mathrm{h}$ rate for a porous $z$ inc electrode. Since the electrolyte is usually $30 \% \mathrm{KOH}$ saturated with $\mathrm{Zn} 0$, the correlation equation in the range of operating current density for the electrolytes in Tabie 3 is

$$
i=\left(4.25 \times 10^{3} \cdot \mathrm{mA}-\mathrm{s}^{1 / 2} / \mathrm{cm}^{2}\right) \mathrm{t}^{-1 / 2}
$$

where $i$ is in $\mathrm{mA} / \mathrm{cm}^{2}$, and $t$ is in $s$. When the current density of $7.4 \mathrm{~mA} / \mathrm{cm}^{2}$ is substituted into Eq. 21, we obtain a passivation time of $9.16 \mathrm{~h}$, which is much longer than the rated period of $2 \mathrm{~h}$. Assuming that the effective interfacial surface area remains constant, we estimated the maximum current density for a $100 \%$ utilization of the electrode without encountering passivation from $\mathrm{Eq} .21$ and the equation of utilization,

$$
Q=10^{-3} i \cdot t
$$

where $Q$ is the capacity of the zinc electrode $\left(\mathrm{C} / \mathrm{cm}^{2}\right)$ at passivation time, $t$, and the factor of $10^{-3}$ is used to convert the current density from $\mathrm{mA} / \mathrm{cm}^{2}$ to $\mathrm{A} / \mathrm{cm}^{2}$. For $100 \%$ electrode utilization, $Q$ is equal to $144 \mathrm{c} / \mathrm{cm}^{2}$. Therefore, we obtain a maximum current density of $125 \mathrm{~mA} / \mathrm{cm}^{2}$ in planar electrodes, which corresponds to a current density of $338 \mathrm{~mA} / \mathrm{cm}^{2}$ in the porous zinc electrode'. A current density of $338 \mathrm{~mA} / \mathrm{cm}^{2}$ is 17 times the designed current density, and probably does not occur even under severe driving conditions. Therefore, we conclude that passivation would not limit the utilization of a newly formed zinc porous electrode.

\section{ACKNOWLEDGMENT}

We thank 2 . Nagy for his valuable comments. 
APPENDIX

Summary of Galvanostatic Data of Zinc in KOH Electrolytes From Previous Studies 
Summary of Galvanostatic Data of Zinc in KOH Electrolytes From Previous Studies

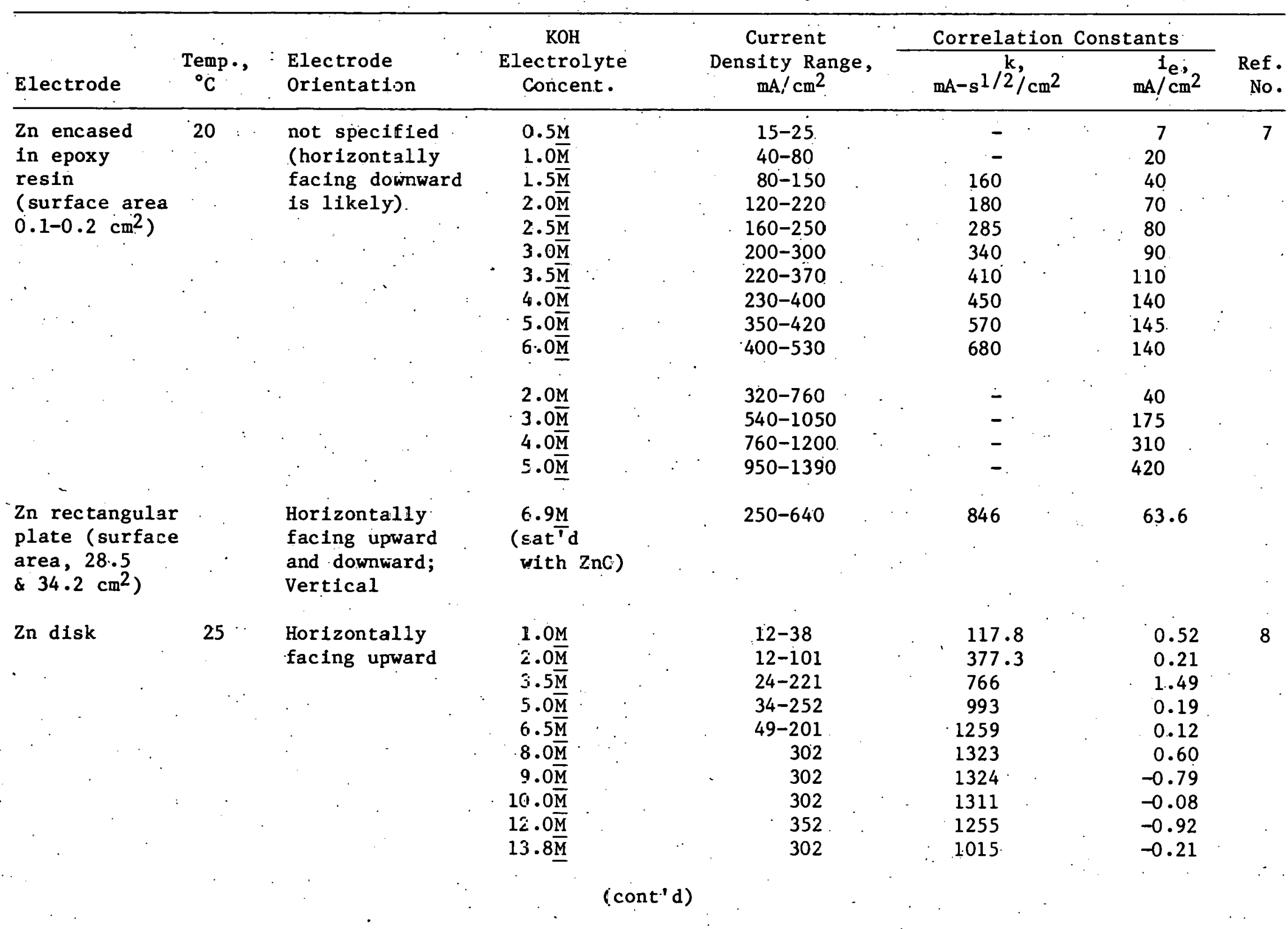


Summary of Galvanostatic Data of Zinc in $\mathrm{KOH}$ Electrolytes From Previous Studies (Cont'd)

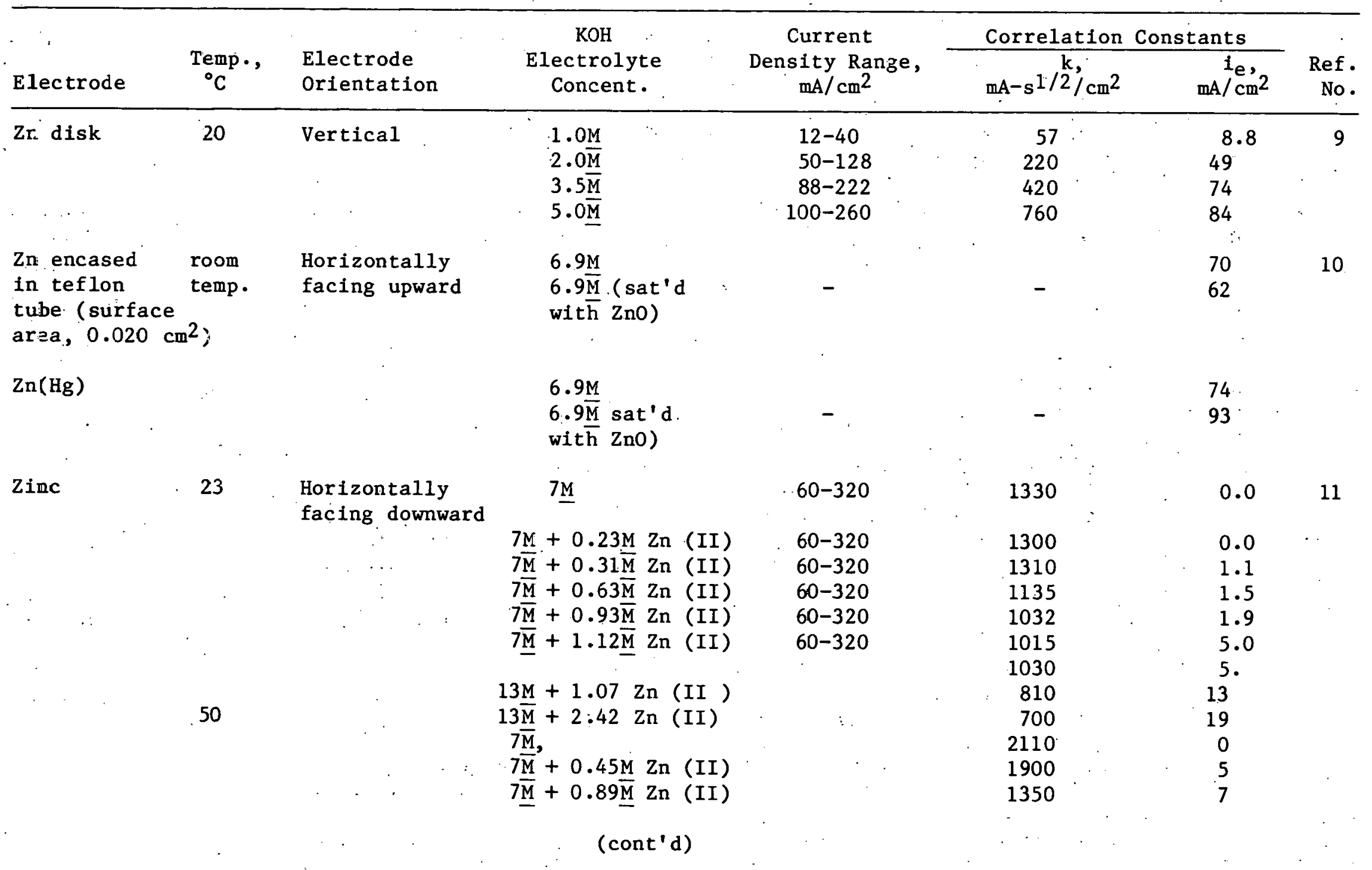


Summary of Galvanostatic Data of Zinc in KOH Electrolytes From Previous Studies (Cont'd)

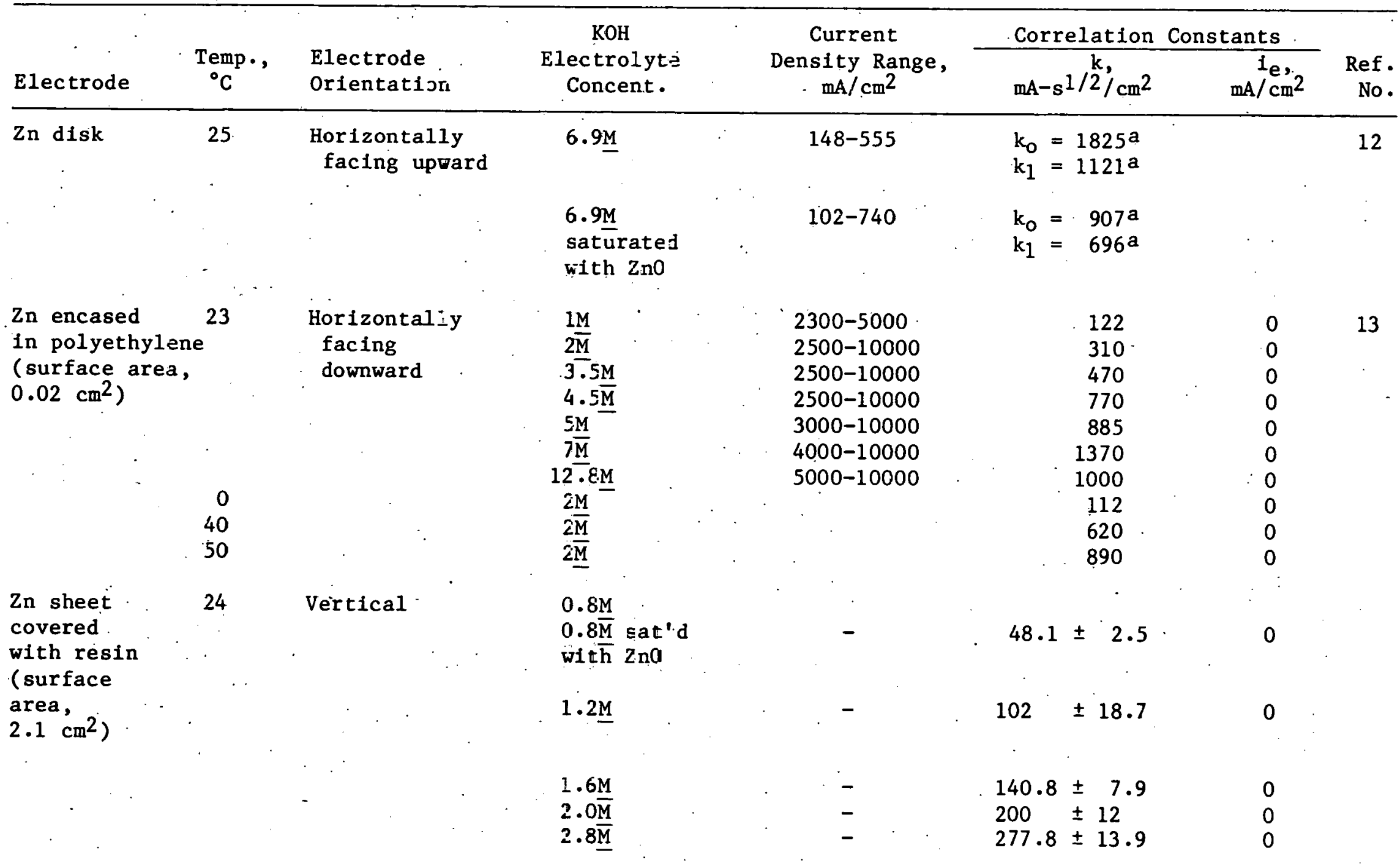

a The data were correlated with the equation, $i \cdot t^{1: 2}=k_{0}-k_{1} \cdot i$.

(cont'd) 
Summary of Galvanostatic. Data of Zinc in KOH Electrolytes From Previous Studies (Cont'd)

\begin{tabular}{|c|c|c|c|c|c|c|c|c|}
\hline \multirow{2}{*}{$\begin{array}{c}\text { Electrode } \\
\end{array}$} & \multirow{2}{*}{$\frac{\begin{array}{c}\text { Temp. } \\
{ }^{\circ} \mathrm{C}\end{array}}{.}$} & \multirow[b]{2}{*}{$\begin{array}{l}\text { Electrode } \\
\text { Orientation }\end{array}$} & \multirow{2}{*}{ 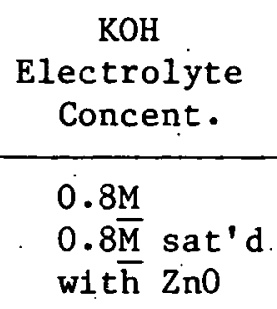 } & \multirow{2}{*}{$\begin{array}{c}\text { Current } \\
\text { Density Range, } \\
\mathrm{mA} / \mathrm{cm}^{2}\end{array}$} & \multicolumn{3}{|c|}{ Correlation Constants } & \multirow[b]{2}{*}{$\begin{array}{l}\text { Ref. } \\
\text { No. }\end{array}$} \\
\hline & & & & & $\frac{\mathrm{k}}{\mathrm{mA}-\mathrm{s}^{1 / 2} / \mathrm{cm}^{2}}$ & $\begin{array}{r}i_{e} \\
\mathrm{~mA} / \mathrm{c}\end{array}$ & & \\
\hline & . & . & $\begin{array}{l}1.2 \mathrm{M} \\
1.6 \overline{\mathrm{M}} \\
2.0 \overline{\mathrm{M}} \\
2.8 \overline{\mathrm{M}}\end{array}$ & $\begin{array}{l}- \\
- \\
-\end{array}$ & $\begin{array}{l}119 \pm 15.6 \\
137 \pm 3.8 \\
172.4 \pm 3.0 \\
222.2 \pm 4.9\end{array}$ & $\begin{array}{r}18.60 \pm \\
35.00 \pm \\
54.21 \pm \\
109.6 \pm\end{array}$ & $\begin{array}{l}2.33 \\
1.96 \\
2.55 \\
6.3\end{array}$ & \\
\hline
\end{tabular}




\section{REFERENCES}

1. W. Van Doorne and T. P. Dirkse, J. Electrochem. Soc. 122,1 (1975).

2. G. H. Newman and G. E. Blomgren, J. Chem. Phys. 43, 2744 (1965).

3. J. S. Fordyce and R. L. Baum, J. Chem. Phys. 43, 843 (1965).

4. R. Landsberg, Z. Phys . Chem. 206, 291 (1957).

5. R. Landsberg and H. Bartelt, Z. Elektrochem. 61 , 162 (1957).

6. M. Eisenberg; H. F. Bauman, and D. M. Brettner, J. Electrochem. Soc. 108,909 (1961.).

7. H. Bartelt and R. Landsberg, Z. Phys. Chem. 222, 217 (1963).

8. N. A. Hampson and M. J. Tarbox, J. Electrochem. Soc. 110, 95 (1963).

9. N. A. Hampson, M. J. Tarbox, L. T. Lilley, and J. P. G. Farr, Electrochem. Technol. 2, 309 (1964).

10. T. P. Dirkse, D. DeWit, and R. Shoemaker, J. Electrochem. Soc. 115 , 442 (1968).

11. N. A. Hampson, P. E. Shaw, and R. Taylor, Br. Corros. J. 4, 207 (1969).

12. J. P. Elder, J. Electrochem. Soc. 116, 757 (1969).

13. I. P. Dirkse, and N. A. Hampson, F.1ertrochim. Acta 16, 2049 (19/1).

14. M. Yamashita, T. Yoshimura, Y. Imanaka, ald H. Furuta, Doshisha Daigaku Rikogaku Kenkyu Hokoku 18, 58. (1977).

15. R. N. Elsdale, N. A. Hampson, P. C. Jones, and A. N. Strachan, J. Appl. Electrochem. 1, 213 (1971):

16. F. Coates, N. A. Hampson, A. Marshall, and D. F. Porter, J. Appl. Electrochem. $\underline{4}, 75$ (1974).

17. R. W. Powers and M. W. Breiter, J. Electrochem. Soc. 116, 719 (1969).

18. S. Szpak and C. J. Gabriel; J. Electrochem. Soc. 126, 1914 (1979).

19. E. A. Ivanov, T. I. Popova, and B. N. Kabanov, Sov. Electrochem. 5, 643 (1969).

20. M. N. Hull and J. E. Toni, Trans. Faraday Soc. 67, 1128 (1971): 
21. R. D. Armstrong, G. M.: Bulman and H. R. Thirsk, J. Electroana1. Chem. $\underline{22}, 55$ (1969).

22. H. Kaesche, Electrochim. Acta 9, 383 (1964).

23. R. W. Powers, J. Electrochem. Soc. 116, 1652 (1969).

24. K. Huber, Helv. Chim. Acta 26, 1037 (1943).

25. K. Huber, J. Electrochem. Soc. 100, 376 (1953).

26. K. Huber, J. Electrochem. Soc. 48, 26 (1942).

27. R. W. Powers, J. Electrochem. Soc. 118, 687 (1971).

28. Z. Nagy and J. O'M Bockris, J. Electrochem. Soc. 119, 285 (1972).

29. T. Katan, J. R. Savory and J. Perkins, J. Electrochem. Soc. 126, 1835 (1979).

30. J. Newman and W. Tiedemann, AIChe J. 21, 25 (1975).

31. W. G. Sunu, Transient and Failure Analysis of Porous Zinc Electrodes, $\mathrm{Ph}$. D. Thesis, Univ. of Calif., Los Angeles (1978).

32. J. McBreen and E. J. Cairns, Advances in Electrochemistry and Chemical Engineering 10, 273 (1978).

33. C. G. Smith, Ellipsometry of Anodic Film.Growth, LBL-8082 (1978).

34. A. Marsha11 and N. A. Hampson, J. Appl. Electrochem. I, 271 (1977).

35. P. Delahay, New Instrumental Methods in Electrochemistry, Interscience Publishers, Inc., New York, NY (1965).

36. A. G. Briggs, N. A. Hampson, and A. Marsha11, Trans. Faraday Soc. 70, 1978 (1974).

37. A. Langer and E. A. Pantier, J. Electrochem. Soc. 115, 990 (1968).

38. H. H. Bode, V. A. Oliapuram, D. Berndt, and P. Ness, Zinc-Silver Oxide Batteries, A. Fleischer and J. L. Lander, Eds. John Wiley \& Sons, Inc., New York, NY, p. 7 (1971).

39. R. D. Naybour, Electrochim. Acta 13, 763 (1968).

40. M. Klein and D. Dube, ANL-K76-3541-1 (1976).

41. M. B. Liu, Y. Yamazaki, G. M. Cook, and N. P. Yao, to be published. 
Distribution for ANL/OEPM-80-1

Internal:

J. J. Barghusen

D. Barney

C. Bean

E. C. Berrill

M. Bl ander

A. Brown

L. Burris

F. A. Cafasso

G. Chapman

A. A. Chilenskas

E. Creamer

C. C. Christianson

G. Cook

D. Corp

W. Deluca

R. C. Elliott

P. R. Fields

D. Fredrickson

B. R. T. Frost

G. T. Garvey
E. C. Gay

J. Geller

M. Genge

J. Harmon

F. Hornstra

C. C. Hsu

$\mathrm{J}$. Klinger

V. Kremesec

A. B. Krisciunas

M. Krumpelt

$M$. Kronénberg

M. L. Kyle

W. W. Lark

T. Lee

M. Liu

R. Lout ty

W. E. Massey

C. A. Melendres

J. Miller

W. Miller
N. Minh

J. Mei senhelder

Z: Nagy

P. A. Nelson

D. Poa

J . Kajan

J. J. Roberts

M. F. Roche

H. Shimot ake

R. K. Steunenberg

C. A. Swoboda

Z. Tomczuk

R. Varma

P. D. Vashishta

D. R. Vissers

D. S. Webster

N. P. Yaov (60)

ANL Contract File

ANL Libraries (5)

TIS Files (6)

\section{External:}

DOE-TIC, for distribution per UC-94ca (315)

Manager, Chicago Operations and Regional office, DOE Chief, office of Patent Counsel, DOE-CORO

V: Hurmme 1, DNE-CORO

J. Purcel1, Chicago Operations office, Argonne, IL President, Argonne Universities Association

Chemical Engineering Division Review Committee:

C. B. Alcock, U. Toronto

R. C. Axtmann, Princeton University

J. T. Banchero, Univ, of Notre Dame

T. Cole, Ford Motor Corp.

P. W. Gilles, Univ. of Kansas

R. I. Newman, Warren, N.J.

H. Perry, Resources for the Future, Washingtor

G. M. Rosenblatt, Pennsylvania State University

W. L. Worrel1, U. of Pennsylvania

S. Abens, Energy Research Corporation; Danbury, CT

E. T. Ames, TRW Systems, Redondo Beach, CA

S. J. Angelovich, Mallory Battery Co., Tarrytown, NY

G. M. Arcand, Idaho State University, Pocatello, ID

G. N. Ault, NASA-Lewis Research Center, Cleveland, OH

A. D. Babinsky, T.R. Evans Research Center, Painesville, OH

K. F. Barber, DOE, Office of Transportation Programs, Washington, DC

T. Barber, Jet Propulsion Laboratory, Pasadena, CA

T. M. Barlow, Lawrence Livermore Laboratory, Livermore, CA

D. Barron, Delco-Remy Div. GMC, Anderson, IN

R. G. Bautista, Iowa State U.

R. Bassett, Sandia Labs, Albuquerque, NM 
L. Belove, Marathon Battery Corp., Waco, TX

D. N. Bennion, Brigham Young University, Provo, UT

J. B. Berkowitz, Arthur D. Little, Cambridge, MA

L. Berkowitz, Esso Research \& Engineering Co., Linden, NJ

C. Berlsterling, Franklin Institute, Philadelphia, PA

E. Berman, TRW Systems Group., McLean, VA

K. Blurton, Institute of Gas Technology, Chicago, IL

D. P. Boden, C\&D Batteries, Plymouth Meeting, PA

$\mathrm{J}$. Bolger, University of California, Berkeley, CA

D. Bowman, United States Postal Service, Washington, DC

J. Brennand, General Research Corp., Santa Barbara, CA

P. Bro, J. R. Mallory \& Co., Inc., Burlington, MA

E. P. Broglio, Eagle-Picher Industries, Joplin, MO

P. J. Brown, DOE, Office of Transportation Programs, Washington, DC

R. Buchholz, Honeywell Corp., Minneapolis, MN

$T$. Burgess, Lucas Industries, Troy, MI

H. Burghart, Cleveland State University, Cleveland, $\mathrm{OH}$

B. W. Burrows, Gould Inc., Rolling Meadows, IL

E. Buzzelli, Westinghouse Electric Corp., Pittsburgh, PA

E. J. Cairns, Lawrence Berkeley Laboratory, Berkeley, CA

P. Campbell, University of Southern California, Los Angeles, CA

R. T. Carpenter, Kimberly Clark Corp. Neenah, WI

T. V. Carvey, Hughes Aircraft Corp., Culver City, CA

T. W. Chapman, U. of Wisconsin, Madison, WI

R. Childs, Energy Research \& Development Corp., Olmsted Falls, OH

L. D. Christian, General Electric, Gainesville, FL

J. E. Clifford, Battelle Memorial Institute, Columbus, $O H$

P. D. Cole, Naval Ordnance Laboratory, Silver Spring, MD

J. G. Colin, Englehard Industries. Inc., Edison, NJ

W. B. Collins, Martin Marietta Corp., Denver, CO

J. E. Cooper, Aero Propulsion Laboratory, Wright-Patterson AFB, OH

K. E. Cox, University of New Mexico, Albuquerque, NM

D. Davis, Lawrence Livermore Laboratory, Livermore, CA

P. Davis, DOE, Office of Transportation Programs, Washington, DC

R. J. Dawson, ESB Inc., Madison, WI

N. A. Demerdash, Virginia Polytechnic Institute, Blacksburg, VA

D. Dharia, Energy Research Corp., Danbury, CT

G. A. DiBari, International Nickel Co., New York, NY

W. J. Dippold, DOE, Office of Transportation Programs, Washington, DC

T. P. Dirske, Calvin College, Grand Rapids, MI

F. M. Donahue, U. of Michigan, Ann Arbor, MI

D. B. Eisenhaure, Charles Stark Draper Lab Inc., Cambridge, MA

M. W. Ellison, Hughes Aircraft Corp., El Segundo, CA

R. P. Epple, Div. of Material Sciences, U.S. DOE, Washington, DC

J. Evans, U: of California, Berkeley, CA

R. E. Evans, Johns Hopkins University, Silver Spring, MD

A. Ewing, DOE, Office of Transportation Programs, Washington, DC

F. Fedor, Bell, Laboratories, Murray Hill, NJ

R. Ferraro, Electric Powèr Research Institute, Palo Alto, CA

A. Fleischer, Orange, NJ

R. F. Fogle, North American Rockwell, Anaheim, CA

R. T, Foley, American University, Washington, DC

J. S. Fordyce, NASA-Lewis Research Center, Cleveland, $\mathrm{OH}$

G. S. Foerster, NL Metals/NL Industries, Hightstown, NJ 
D. N. Goens, Hazen Research, Golden, CO

G. Goodman, Globe-Union Inc., Milwaukee, WI

R. E. Goodson, Purdue University, W. Lafayette, IN

C. B. Graff, NASA-George C. Marshall Space Flight Center, Huntsville, AL

J. A. S. Green, Martin Marietta Laboratories, Baltimore, MD

R. Guess, General Electric Research Lab, Schenectady, NY

R. G. Gunther, General Motors Research Labs, Warren, MI

G. Hagey, DOE, Division of Technology Overview, Washington, DC

G. Halpert, NASA-Goddard Space Flight Center, Greenbelt, MD

H. Hamilton, University of Pittsburgh, Pittsburgh, PA

B. Hamling, Zircar, Florida, NY

V. Hampe 1; Lawrence Livermore Laboratory, Livermore, CA

K. L. Hanson, General Electric Co., Philadelphia, PA

J. H. Harrison, Naval Ship R\&D Center, Annapolis, MD

G. Hartman, ESB Incorporated, Yardley, PA

J. Hartman, General Motors Research Labs, Warren, MI

E. A. Henry, U. of California, Livermore, CA

V. Hlavin, NASA-Lewis Research Center, Cleveland, $\mathrm{OH}$

G. Hobbib, ESB Inc, Cleveland, $\mathrm{OH}$

J. E. Hoffmann, Exxon Research and Engineering Co., Florham Park, NJ

R. Hudson, Eagle-Picher Industries, Joplin, MO

H. L. Hughes, Oklahoma State University, Stillwater, OK

W. B. Iaconel1i, Ionics Inc., Watertown, MA

G. H. Jantz, Rensselaer Polytechnic Institute, Troy, NY

W. P. Jensen, Idaho National Engineering Laboratory', Idaho Falls, ID

L. Jok1; MERADCOM, Fort Belvoir, VA

W. J. Jones, Westinghouse Electric Corp., Pittsburgh, PA

J. Jorné, Wayne State U., Detroit, MI

W. Juda, Prototech, Inc. Newton Highlands, MA

E. Kanter, Gulton Battery Corp., Metuchen, NJ

N. Kaplan, Harry Viamond Laboratories, Washinglou, DC

T. Katan, Lockheed Palo Alto Research Laboratory, Palo Alto, CA

J. A. Kerrella, Delco-Remy Division/GMC, Anderson, IN

R. A. Keyes, Robert A. Keyes Associates, Martinsville, IN

W. C. Kincaide, Teledyne Energy Systems, Timonium, MD

R. Kirby, U. S. Bureau of Mines, Washington, DC

R. S. Kirk, DOE, Office of Transportation Programs, Washington, DC

K. Klein, U. S. Department of Energy, Washington, DC

J. G. Krisilas, Aerospace Corporation, E1 Segundo, CA

V. Kudryk, ASARCO Inc.; South Plainfield, NJ.

A. Landgrebe, U. S. Department of Energy, Washington, DC

R. Lund, St. Joe Minerals Corp., Monaca, PA

J. Mader, Electric Power Research Institute, Palo Alto, CA

$\mathrm{J}$. Maisel, Cleveland State University, Cleveland, $\mathrm{OH}$

R. E. Maizell, Olin Research Center, New Haven, CT

$V$. Manson, National Aeronautics and Space Adm., Washington, DC

C. E. May, NASA-Lewis Research Center, Cleveland, OH

J. McBreen, Brookhaven - National Laboratory, Üpton, NY

B. Mc Cormick, Los Alamos Scientific Labs; Los Alamos, NM

L. A. McCoy, E. I. duPont de Nemours \& Co., Wilmington, DE

L. R. McCoy, Atomics. International, Canoga Park, CA

J. Mckeown, DOE, Office of Program Administration, Washington, DC

R. P. Mikkelson, General Dynamics, San Diego, CA

D. G. Miley, U.'S. Naval Ammunition Depot, Crane, IN 
F. J. Mollura, Rome Air. Development Center, Griffiss AFB, NY

F. Moore, DOE, Energy Storage Systems, Washington, DC

J. Moseley, Dow Chemical R\&D, Pittsburgh, CA

A. Moss, Leesona Moos Laboratories, Warwick, RI

T. Mukherjee, National Science Foundation, Washington, DC

J. P. Mulling, National Aeronautics and Space Adm., Washington, DC

G. Murphy, Northwestern University, Evanston, IL

N. T. Musial, NASA-Lewis Research Center, Cleveland, $\mathrm{OH}$

H. V. Nadham, Bogue Batteries, E1 Segundo, CA

W. J. Nagle, NASA-Lewis Research Center, Cleveland, $\mathrm{OH}$

M. M. Nickolson, Atomics International Division, Canoga Park, CA

K. Nobe, U. of California, Los Angeles, CA

J. Norberg, ESB. Inc., Philadelphia, PA

W. Opie, AMAX Inc., Carteret, NJ

B. N. Otzinger, North American Aviation, Downey, CA

J. E. Oxley, Gould Inc., Rolling Meadows, IL

J. S. Parkinson, Johns-Manville R\&D Center, Manville, NJ

C. Pax; DOE, Office of Transportation Programs, Washington, DC

J. P Pemsler, Castle Technology Corporation, Lexington, MA

G. F. Pezdirtz, DOE, Energy Storage Systems, Washington, DC

A. G. Plunckett, General Electric R\&D Center, Schenectady, NY

V. J. Pugli.si, Yardney Electric Corp., Pawcatuck, CT

E. Raskin, USAF Cambridge Research Laboratory, Bedford, MA

A. D. Raynard, AiResearch Manufacturing Co., Torrance, CA

H. L. Recht, Atomics International Division, Canoga Park, CA

E. Rizkalla, DOE, Washington, DC

L. Rosenblum, NASA-Lewis Research Center, Cleveland, OH

N. Rosenburg, Department of Transportation, Cambridge, MA

R. Rosey, Westinghouse Electric Corp., Pittsburgh, PA

J. W. Ross, Texas Instruments Inc., Attleboro, MA

J. Rossmon, Cornell University, Ithaca, NY

G. Rowland, General Electric, Schenectady, NY

J. Rubenzer; NASA-Ames Research Center, Moffett Field, CA

A. J. Salkind, Rutgers Medical School

I. O. Salyer, Monsanto Research Corp., Dayton, $\mathrm{OH}$

F. J. Salzano, Brookhaven National Laboratory, Upton, NY

D. F. Schmidt, General Electric Co., Washington, DC

L. W. Schopen, NASA-Lewis Research Center, Cleveland, OH

S. Schuldiner, Naval Research Laboratory, Washington, DC

W. R. Scott, TRW Systems Inc., Redondo Beach, CA,

H. Seiger, Waterford, CT

I. Servi, Kennecott Copper Corporation, Lexington, MA

R. C. Shair, Hollywood, FL

H. Shalit, ARCO Chemical Corp., Glenolden, PA

D. W. Sheibley, NASA-Lewis Research Center, Cleveland, OH

G. P. Smith, Oak Ridge Nationdl Laboratory, Oak. Ridge, I'N

J. Smits, Nevada Operations Office, DOE, Las Vegas, NV

F. Solomon, Electrode Media, Inc., Englewood, NJ

G. M. Thur, DOE, Office of Iransportation Programs, Washington, DC

B. V. Tilak, Hooker Research Center, Grand Island, NY

L. Topper, National Science Foundation, Washington,

I. Trachtenberg, Texas Instruments, Dallas, TX

L. E. Vaaler, Battelle Columbus Laboratories, Columbus, $\mathrm{OH}$

C. J. Venuto, C\&D Batteries, Plymouth Meeting, PA 
M. E. Wadsworth, U. of Utah, Salt Lake City; UT

R. D. Wherle, Sandia Labs, Albuquerque, NM

T. C. Wilder, Lexington, MA

M. E. Wilke, Burgess Battery Company., Freeport, IL

J. M. Williams, E. I. duPont de Nemours \& Co., Wilmington, DE

E. Willihnganz, C\&D Batteries, Plymouth Meeting, PA

J. F. Wing, Booz-Allen \& Hamilton Inc., Bethesda, MD

J.'C. Withers, Pora, Inc., Berea, $\mathrm{OH}$.

J. Wooldridge, Boeing Corp., Seattle, WA

V. Wouk, Petro-Electric Motor Ltd.; New York, NY

L. Yanni, Booz-Allen \& Hamilton Inc., Bethesda, MD

J. E. Zanks, NASA-Langley Research Center, Hampton, VA

M. Zlotnick, DOE, Conservation Research and Technology, Washington, DC

N. R. Bharucha, Noranda Research Center, Pointe Claire, Quebec, Canada

B. E. Conway, U. of Ottawa, Ontario; Canada

V. Ettel, INCO, Mississauga, Ontario, Canada

H. H. Horowitz, Alsthom-Exxon, Massy, France

N: Ibl, Technisch-Chemisches Laboratorium, "Zurich, Swilzerlaud

D. Landolt, Swiss Federal Institute of Technology, Lausanne, Switzerland 